\title{
Review
}

\section{Obesity and Pancreatic Cancer: Insight into Mechanisms}

\author{
Guido Eibl ${ }^{1, *} *$ (i) and Enrique Rozengurt ${ }^{2}(\mathbb{0})$ \\ 1 Department of Surgery, David Geffen School of Medicine at UCLA, Los Angeles, CA 90095, USA \\ 2 Department of Medicine, David Geffen School of Medicine at UCLA, Los Angeles, CA 90095, USA; \\ ERozengurt@mednet.ucla.edu \\ * Correspondence: Geibl@mednet.ucla.edu
}

check for

updates

Citation: Eibl, G.; Rozengurt, E. Obesity and Pancreatic Cancer: Insight into Mechanisms. Cancers 2021, 13, 5067. https://doi.org/ 10.3390/cancers13205067

Academic Editor: Murray Korc

Received: 15 September 2021

Accepted: 8 October 2021

Published: 10 October 2021

Publisher's Note: MDPI stays neutral with regard to jurisdictional claims in published maps and institutional affiliations.

Copyright: (C) 2021 by the authors. Licensee MDPI, Basel, Switzerland. This article is an open access article distributed under the terms and conditions of the Creative Commons Attribution (CC BY) license (https:// creativecommons.org/licenses/by/ $4.0 /)$.
Simple Summary: Obesity is recognized as a chronic progressive disease and risk factor for many human diseases. The high and increasing number of obese people may underlie the expected increase in pancreatic cancer cases in the United States. There are several pathways discussed that link obesity with pancreatic cancer. Adipose tissue and adipose tissue-released factors may thereby play an important role. This review discusses selected mechanisms that may accelerate pancreatic cancer development in obesity.

Abstract: The prevalence of obesity in adults and children has dramatically increased over the past decades. Obesity has been declared a chronic progressive disease and is a risk factor for a number of metabolic, inflammatory, and neoplastic diseases. There is clear epidemiologic and preclinical evidence that obesity is a risk factor for pancreatic cancer. Among various potential mechanisms linking obesity with pancreatic cancer, the adipose tissue and obesity-associated adipose tissue inflammation play a central role. The current review discusses selected topics and mechanisms that attracted recent interest and that may underlie the promoting effects of obesity in pancreatic cancer. These topics include the impact of obesity on KRAS activity, the role of visceral adipose tissue, intrapancreatic fat, adipose tissue inflammation, and adipokines on pancreatic cancer development. Current research on lipocalin-2, fibroblast growth factor 21, and Wnt5a is discussed. Furthermore, the significance of obesity-associated insulin resistance with hyperinsulinemia and obesity-induced gut dysbiosis with metabolic endotoxemia is reviewed. Given the central role that is occupied by the adipose tissue in obesity-promoted pancreatic cancer development, preventive and interceptive strategies should be aimed at attenuating obesity-associated adipose tissue inflammation and/or at targeting specific molecules that mechanistically link adipose tissue with pancreatic cancer in obese patients.

Keywords: obesity; pancreatic cancer; adipose tissue; intrapancreatic fat; inflammation; adipokine; gut microbiome

\section{Introduction}

The prevalence of obesity in adults and children is increasing in the United States of America and in many other countries as well. Obesity is a well-recognized risk factor for a plethora of diseases, including pancreatic cancer. There are several potential mechanisms by which obesity may lead to an increase in pancreatic cancer incidence. However, the precise causal mechanism(s) are still poorly understood and may consist of a combination of local and systemic perturbations induced by the obese state. A better understanding of molecules and molecular signaling pathways driving pancreas cancer development and growth are of utmost importance to develop targeted prevention/interception strategies. The scope of the present review is not to provide a comprehensive, all-encompassing summary of all studies published on obesity and pancreatic cancer. Rather, the authors discuss selected mechanisms that in their opinion are of current interest and warrant further investigation. 


\section{Epidemiology of Obesity and Pancreatic Cancer}

The global prevalence of obesity has almost tripled since 1975 [1]. In 2016, more than 1.9 billion adults $(39 \%)$ were overweight (body mass index (BMI) $\geq 25$ ) with over 650 million $(13 \%)$ of those being obese (BMI $\geq 30$ ) [1]. Alarmingly, more than 340 million children and adolescents (ages 5-19) were overweight or obese in 2016 and 39 million children younger than 5 years of age were overweight or obese in 2020 [1]. In the United States of America, the latest data brief from the National Center for Health Statistics reports a prevalence of obesity in adults aged 20 years or older of $42.4 \%$ in $2017-2018$, which is a considerable increase from $33.7 \%$ in $2007-2008$ [2]. There is no doubt that obesity is an enormous burden on the individual's health and on society as a whole. Obesity itself is now declared a chronic progressive disease and in addition a risk factor for multiple human diseases including several types of cancer [3-5].

Pancreatic ductal adenocarcinoma (PDAC), the most common histologic subtype of cancers of the pancreas, continues to be a very aggressive and lethal type of cancer. The American Cancer Society has reported an estimated 60,430 new cases (28,480 females and 31,950 males) of pancreatic cancers in the year 2021 [6]. In the same calendar year, an estimated 22,950 female and 25,270 male patients will die of this disease, ranking pancreatic cancer as the third leading cause of cancer mortality in women and men combined [6]. In contrast, the estimates for pancreatic cancer prevalence in 2016 were 53,070 (25,400 females and 27,670 males) [7], which calculates to an almost $13.9 \%$ increase $(12.1 \%$ in females and $15.5 \%$ in males) in total estimated pancreatic cancer cases over the last 5 years. Indeed, the mortality of pancreatic cancers is projected to surpass the deaths from colorectal cancer by 2030, catapulting pancreatic cancers to the second leading cause of cancer-related deaths in the United States [8]. The rising prevalence of obesity over the past decades may thereby be a significant contributing factor to the observed and expected increase in pancreatic cancer cases and mortality.

A positive correlation between obesity and PDAC risk has been firmly established [3,9-14]. According to the National Institutes of Health $16.9 \%$ of all cases of PDAC in the United States can be attributed to obesity (in contrast cigarette smoking is estimated to be the causative factor in $10.2 \%$ of PDAC cases) [15]. In that context, the age of onset and duration of obesity seems to be an important factor in conferring PDAC risk. The length of time of being overweight was longer in patients with PDAC compared to controls, and the highest odds ratio for obesity was found in 30-39 year old subjects without diabetes [16]. Importantly, the association between obesity and risk of PDAC was stronger in men than in women [16]. Besides the importance of early adulthood, growing evidence suggests that adolescent and childhood obesity is also linked to an increased risk of developing PDAC later in life [17-20]. Here, it is imperative to distinguish the effect of obesity during early cancer development (risk factor for early tumor promotion) from its sometimes-paradoxical effects in the late-stage, advanced disease, where obesity occasionally appears to be associated with improved outcome (obesity paradox) [21-23]. It has been suggested that the lack of tumor cachexia (loss of muscle mass) in obese patients with advanced cancer may underlie the obesity paradox [24]. Taken together, the available evidence from epidemiologic studies clearly points to obesity as a risk factor for (early) PDAC development. Prevention of obesity, especially during childhood, adolescence, and early adulthood, is of paramount importance to curtail the expected rise in PDAC cases and mortality. A more detailed and comprehensive understanding of mechanisms that underlie the promotional effects of obesity on PDAC is necessary to identify and exploit potential molecular targets and to develop preventive and/or interceptive strategies.

\section{Mouse Models of Obesity and Pancreatic Cancer}

It is widely accepted that KRAS mutations are critical initiating drivers of PDAC $[25,26]$. Preclinical animal models are instrumental for the study of risk factor-promoted PDAC development. Endogenous Kras models, which express mutated Kras conditionally from its endogenous gene locus, are considered as state-of-art models for PDAC and are widely 
used $[27,28]$. This model faithfully recapitulates human PDAC histopathologically and genetically, including the development of pancreatic intraepithelial neoplasias (PanIN-1 to -3), recognized precursor lesions of PDAC, and the presence of a desmoplastic reaction. For the conditional Kras mouse model of PDAC development $L S L-K r a s{ }^{G 12 D}$, mice are normally crossed with either $p t f 1 a$ (p48)-Cre or $p d x$-Cre mice (KC). Offspring with successful recombination will develop PanINs with complete penetrance [29]. About $5-10 \%$ of the animals will develop PDAC at about 9-12 months [29]. The KC mouse model has been crossed into various gene-deficient or mutated backgrounds, e.g., p53 (murine Trp53), most of which greatly accelerate the development of PDAC and shorten survival [30,31]. Since the transcription factors $\mathrm{p} 48$ or $\mathrm{pdx}$ are expressed in pancreatic progenitor cells during early pancreas development, all adult pancreas lineages, which include acinar, ductal, and endocrine lineages, harbor the mutated Kras. Studies have shown that KC mice do not accumulate additional changes in genes that are the most commonly mutated in human PDAC (e.g., p16Ink4a, Trp53, and Smad4) during PanIN development [32]. Besides the mouse model described above, in which oncogenic Kras is expressed during pancreatic embryological development, transgenic mouse models have been developed that allow for inducible and reversible expression of the oncogenic KrasG12D in the pancreas [33-35]. These inducible models are very valuable to study the temporal efficacy of oncogenic Kras to drive and maintain pancreatic carcinogenesis. Furthermore, using elastase-cre or CK19-cre (or Sox9-cre) strains, the expression of oncogenic Kras can be targeted to pancreatic acinar or ductal cells, respectively [36-41].

Preclinical studies employing the aforementioned mouse models have convincingly demonstrated that obesity accelerates PDAC development, thus providing an invaluable platform to study the obesity-PDAC link. Although oncogenic Kras mutations are thought of initiating factors for PDAC (see below), obesity is thought to be a tumor-promoting factor, especially during early neoplastic development. We and others have reported that (high-fat) diet-induced obesity (DIO) hastens the formation of PanINs and the progression to PDAC [37,42-44]. This is generally accompanied by weight gain and metabolic disturbances, e.g., hyperinsulinemia and hyperleptinemia, which are also seen in human obesity. In addition, DIO is accompanied by a strong fibro-inflammatory reaction in the pancreas of KC mice with elevated tissue levels of several pro-inflammatory cytokines, chemokines, and growth factors [42,43]. The importance of inflammation and the efficacy of anti-inflammatory drugs on PDAC development in $\mathrm{KC}$ mice has been reported previously [45]. Besides mouse models with DIO, a recent study showed that KC mice with genetic obesity (Pdx1-Cre;LSL-KrasG12D/+ mice crossed with leptin-deficient [ob/ob] mice) also developed PDAC faster and succumbed to the disease earlier [46]. Taken together, there is unambiguous evidence from preclinical mouse models that obesity (DIO or genetic) promotes PDAC.

\section{Mechanisms Linking Obesity and Pancreatic Cancer}

Several mechanisms are usually discussed by which obesity may promote (pancreatic) cancer development and progression, including systemic chronic inflammation, adipokines, sex hormones, hyperinsulinemia, and gut microbiome [47-51]. Although certainly not exhaustive, selected potential mechanisms are discussed below.

\subsection{Influence of Obesity on Kras Activity}

Oncogenic mutations in KRAS are thought to be an initiating event in human PDAC, which is strongly supported by preclinical mouse models. It is well documented that the vast majority of human PDACs contain a KRAS mutation (most commonly G12D), which can be found also in early-stage PanINs [52]. Recent exome sequencing studies confirmed that KRAS is the most frequently mutated gene found in PDAC ( 95\%) [53,54]. However, data from mouse models have clearly shown that Kras mutant cells do not readily form early PanIN-1 lesions, despite the expression of mutant Kras in every pancreatic epithelial cell $[29,55]$. It seems that mutated Kras alone is rather insufficient to drive pancreatic 
neoplasia, but additional genetic, epigenetic, and/or microenvironmental changes may be required [55]. Non-genetic perturbations in the pancreatic microenvironment, as putatively induced in the obese state, may thereby be especially critical in the early stages of pancreatic neoplastic development [26,55].

Considering the importance of oncogenic Kras and the known promoting effects of obesity in PDAC, it is conceivable to consider a direct effect of obesity and/or the obesogenic diet on Kras activity. Based on the observation that only a small percentage of mutated Kras is occupied with guanosine triphosphate (GTP) and thus cannot be considered constitutively active [56], Logsdon and colleagues postulated a Ras/Inflammation Feed Forward model, in which oncogenic Kras requires activation by external/inflammatory factors, e.g., as found in obesity, to drive pancreatic neoplasia $[57,58]$. Once the activity of oncogenic Kras has exceeded a certain threshold, it can generate its own inflammatory mediators, which in turn feed-back to further stimulate Kras activity [57,58], thereby driving cancer development. These external/inflammatory mediators can comprise a variety of factors, including inflammatory cytokines, eicosanoids, and other ligands of receptor tyrosine kinases and G protein-coupled receptors (GPCRs) [57]. Based on this paradigm, the pancreas from LSL-Kras/Ela-CreERT mice, which were fed high-fat diets, had elevated Kras activity, elevated phospho ERK, increased pancreatic inflammation, fibrosis, and neoplastic lesions [37]. However, these considerations were based on pull down assays of Kras-GTP that do not take into account the effect of Kras tyrosine phosphorylation on the affinity for the Ras-binding domain of RAF [59]. In our opinion, it will be important to reinvestigate the activity of Kras in the setting of DIO using additional assays. In our own studies, we have observed activation of signaling molecules that may be downstream of Kras, e.g., increased levels of phosphorylated mitogen-activated protein kinase (MEK), extracellular signal-regulated kinases (ERK), and S6, in the pancreas of KC mice with DIO [60].

\subsection{Adipose Tissue and Obesity-Associated Meta-Inflammation}

Contrary to initial depictions as simply an energy storage tissue, adipose tissue (AT) is now known to be a metabolically and hormonally highly active and dynamic organ that is capable of responding to a variety of internal and external stimuli and synthesizing a large range of biologically active peptides. In turn, AT-derived mediators regulate many physiological and pathophysiological processes, e.g., food intake, insulin sensitivity, immunity, and inflammation [61,62]. These peptides include adipokines, e.g., leptin, adiponectin, and lipocalin-2, which are mainly secreted by adipocytes, as well as ATderived factors, including IL- 6 and TNF- $\alpha$, which can be also be secreted by cells other than or in addition to adipocytes, e.g., macrophages [62]. Generally, AT can influence PDAC development systemically via soluble mediators that are released from distant (visceral) fat depots and reach the pancreatic microenvironment through the systemic circulation or via paracrine effects elicited by intrapancreatic adipocytes (see below) [63,64]. A mechanism that is receiving increasing attention is communication via extracellular vesicles from adipocytes that can fuse with target cells in the pancreas [65-67]. It has been shown recently that adipocytes experience strong energetic stress during obesity, which resulted in the release of small extracellular vesicles harboring respiration-competent, but oxidatively damaged, mitochondrial fragments, which access the systemic circulation and are internalized by cardiomyocytes [68]. It is intriguing to think that during obesity, adipocytes communicate with transformed and non-transformed pancreatic cells via extracellular vesicles, thereby promoting tumor development. Specific studies would be required to test this hypothesis.

\subsubsection{Visceral Adipose Tissue}

The defining characteristic of obesity is the enlargement and expansion of white adipose tissue, which can occur via hyperplasia and/or hypertrophy. While adipocyte hyperplasia, which is more often seen in subcutaneous AT, is usually associated with low levels of AT inflammation and maintained insulin sensitivity, adipocyte hypertrophy 
predominates in visceral AT (VAT) and correlates with pro-inflammatory responses and impaired insulin sensitivity [69]. Hypertrophic adipocytes can experience hypoxia and undergo stress responses and cell death, leading to the secretion of pro-inflammatory factors, an increase in pro-inflammatory immune cell infiltration, and the deposition of lipid molecules ectopically in other organs. This is particularly important as the VAT (omental, mesenteric, and other intra-abdominal fat pads), and VAT inflammation is the main source of the systemic and local chronic inflammation in the obese state [70] and is more strongly associated with metabolic dysfunction and cancer than subcutaneous fat $[12,71-73]$. VAT (but not subcutaneous fat) is significantly correlated with the number of PanINs [74]. In our own studies, more PDACs developed in obese male KC mice [42], which displayed a preferential expansion of VAT, as compared to obese female mice that favored subcutaneous fat gain [75].

\subsubsection{Adipose Tissue Inflammation}

VAT has been shown to be the predominant source of the systemic, low-grade, chronic inflammation seen in obesity (also called meta-inflammation [76]) and most important for the development of type 2 diabetes mellitus (T2DM) [77,78]. VAT contains a great variety of immune cells, the composition of which is significantly altered in the obese state [78]. An important early step in the development of obesity-induced VAT inflammation is the switch of anti-inflammatory M2 macrophages to a pro-inflammatory M1-like phenotype [78,79]. These M1-like macrophages are thought to be the main source of systemic pro-inflammatory cytokines in obese and/or diabetic subjects [78]. Obesity-associated AT inflammation is characterized by the generation and secretion of multiple inflammatory cytokines and chemokines, including but not limited to interleukin-6 (IL-6), tumor necrosis factor- $\alpha$ (TNF- $\alpha$ ), IL-1 $\beta$, IL-18, and monocyte chemoattractant protein-1 (MCP-1) [78]. It is conceivable that the systemic elevation of these inflammatory mediators, secreted from the VAT in obese subjects, may bind to their cognate receptors on transformed pancreatic epithelial cells, thereby conferring a proliferative and pro-survival benefit. Our studies (unpublished) showed that the cell culture supernatant of the VAT stromal vascular fraction (all cellular components except mature adipocytes) and of direct VAT explants of obese KC mice robustly stimulated DNA synthesis and oncogenic signaling pathways in murine PanIN cells (Figure 1). These results indicate that soluble factors from the VAT, in particular mesenteric fat, have direct proliferative effects on (pre)malignant pancreatic epithelial cells.

Furthermore, the systemically elevated factors in the obese condition may also stimulate neoplastic pancreatic epithelial cells and/or non-malignant cells in the pancreatic stroma, e.g., cancer-associated fibroblasts, infiltrating/resident immune cells, and intrapancreatic adipocytes (see below), to generate locally inflammatory cytokines and chemokines. Locally produced chemokines can further recruit immune cells, e.g., circulating monocytes, into the pancreatic microenvironment, where they can contribute to and reinforce local tissue inflammation and cancer cell growth [80]. The importance of paracrine signaling in the pancreatic microenvironment to oncogenic Kras-driven metabolic reprogramming and tumor growth has recently been reported [81]. We previously demonstrated elevated pancreatic tissue levels of several cytokines and chemokines, e.g., IL-6, TNF- $\alpha$, and MCP-1, in obese $\mathrm{KC}$ mice that were fed a diet high in fat and calories [43]. Interestingly, while lean KC mice (fed a control diet) also had elevated pancreatic tissue levels of these cytokines/chemokines compared to wild-type mice (lean and obese), obese KC had even significantly higher levels [43], suggesting a positive reinforcement between oncogenic Kras and obesity/high-fat diet. 
A)

$\frac{15 \mathrm{~min}}{-1 / 3 \times 1 \times \mathrm{CM}} \frac{30 \mathrm{~min}}{-1 / 3 \times 1 \times \mathrm{CM}} \frac{1 \mathrm{hr}}{-1 / 3 \times 1 \times \quad \mathrm{CM}}$

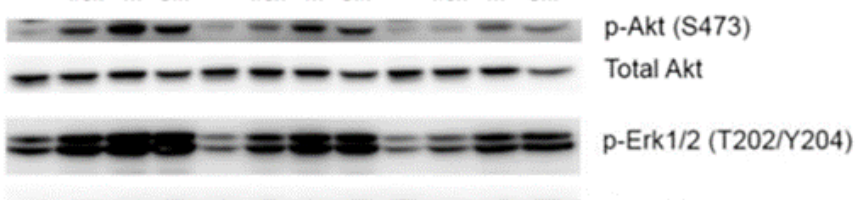

$=\mathrm{z}=\mathrm{z}=\mathrm{z}=\mathrm{z}=\mathrm{E}=$ Total Erk

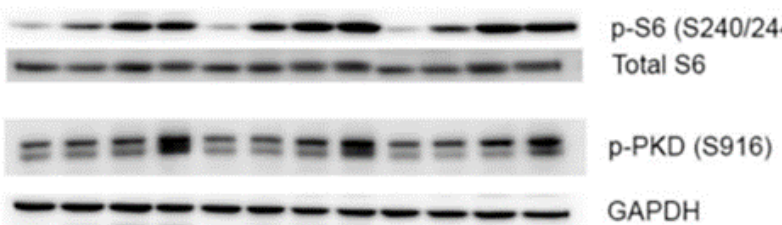

B)
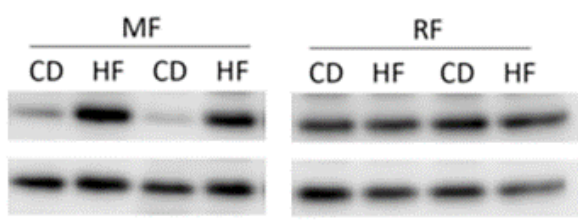

p-S6 (S240/244)

Total S6

Figure 1. Soluble factors released from adipose tissue stimulate pro-oncogenic signaling pathways in pancreatic cancer cells. (A) Mesenteric adipose tissue from obese KC mice was harvested and cultured in vitro. Murine pancreatic cancer cells were incubated with the culture supernatant (undiluted $(1 \times)$ or diluted $(1 / 3 \times)$ for 15,30 , and $60 \mathrm{~min}$ and phosphorylation of pro-oncogenic signaling molecules detected by Western blotting. Total forms of the signaling molecules or glyceraldehyde 3-phosphate dehydrogenase (GAPDH) were used as loading controls. Serum-free culture medium (-) or complete culture medium with $10 \%$ fetal bovine serum $(\mathrm{CM})$ served as negative and positive controls, respectively. (B) Mesenteric (MF) and retroperitoneal (RF) adipose tissues from obese (high fat: HF) or lean (control diet: CD) KC mice ( $n=2$ in each group) were harvested and cultured in vitro. Murine pancreatic cancer cells were incubated with the culture supernatant for $30 \mathrm{~min}$ and phosphorylation of S6 was measured by Western blotting. Total S6 served as a loading control. Data are authors' own unpublished results.

\subsubsection{Leptin}

The first adipokine identified in 1994, leptin, is a $16 \mathrm{kDa}$ hormone encoded by the $o b$ gene, the murine homologue of the human LEP gene [82]. It binds to leptin receptors (Ob-R), members of the class I cytokine receptor family, and activates mainly the Janus kinase/signal transducer and activator of transcription (JAK/STAT) signaling pathway [83-85]. Leptin is secreted mainly by adipocytes and its primary function is to decrease food intake and increase energy expenditure (anorexigenic) mainly through its actions in the hypothalamus [86,87]. As leptin expression correlates to adipose mass, obese subjects display elevated plasma leptin levels [88,89]. Since elevated leptin levels in obese patients do not lead to decreased food intake and increased energy expenditure, the obesityassociated hyperleptinemia is thought to reflect leptin resistance [90]. The role of leptin in PDAC development and growth is still controversial. In a pooled, nested case-control study, increased leptin concentrations correlated with pancreatic cancer, but only after a long follow-up of 10 or more years [91]. In another prospective, nested case-control study, higher leptin levels correlated with an increased risk of pancreatic cancer in men, but not women [92]. Results from a large Mendelian randomization study did not support a causal effect of plasma leptin levels on pancreatic cancer development [93]. In preclinical animal studies, KC mice with DIO developed hyperleptinemia [42,43], suggesting a relationship between leptin and PDAC. Caloric restriction in KC mice was associated with decreased leptin levels and a delay in PDAC development [94]. However, KC mice with genetic obesity (Pdx1-Cre;LSL-KrasG12D/+ mice crossed with ob/ob mice) that are leptin deficient 
also developed PDAC faster, arguing against a causative role of leptin in PDAC [46,95]. Furthermore, KC mice with genetic deficiency in hormone-sensitive lipase had decreased plasma leptin levels but accelerated PDAC development [96]. In vitro studies have demonstrated that PDAC cells express functional leptin receptors $(\mathrm{Ob}-\mathrm{Rb})$ and exposure to leptin stimulates migration, invasion, and proliferation of PDAC cells [97-99]. These effects were mediated by activation of several signaling pathways, including the phosphoinositide 3-kinase/protein kinase B (PI3K/Akt) and JAK2/STAT3 pathways. In addition, the leptin-Notch axis seems to play a role in proliferation and chemoresistance in PDAC cell cultures [100-102]. Taken together, although in vitro experiments clearly demonstrated functional leptin receptor expression and various direct effects of leptin in PDAC cells, the cumulative data from preclinical animal and epidemiologic studies at least question a causative role of leptin in obesity-promoted PDAC.

\subsubsection{Adiponectin}

First described in 1995 [103], adiponectin is a $\sim 30 \mathrm{kDa}$ protein secreted mostly by the white adipose tissue and possesses anti-diabetic, anti-inflammatory, anti-atherogenic, and anti-angiogenic properties $[104,105]$. Adiponectin binds to AdipoR1 and AdipoR2 receptors, which, contrary to all known G protein-coupled receptors (GPCRs), are seven transmembrane domains containing membrane proteins that have their amino terminus intracellularly and their carboxy terminus extracellularly [105]. Binding of adiponectin to its receptors leads to hydrolysis of ceramide to sphingosine. Sphingosine kinases can then phosphorylate sphingosine to sphingosine-1-phosphate (S1P) [104], which activates S1P receptors, a class of GPCRs. Further downstream of ceramide hydrolysis and sphingosine formation, but also through ceramide-independent pathways, AdipoR can activate PI3K, Akt, adenosine monophosphate-activated protein kinase (AMPK), and calcium $\left(\mathrm{Ca}^{2+}\right)$ release $[104,106]$. Despite its secretion by adipocytes, adiponectin plasma levels are paradoxically decreased in obesity $[104,107,108]$. The currently available evidence of an association of adiponectin levels and PDAC risk is conflicting. Higher adiponectin concentrations were found to be inversely associated with PDAC in male smokers, which was significant among cases diagnosed 5 or more years after blood collection [109]. Analyzing 468 PDAC cases and 1080 matched controls from five prospective US cohorts, plasma adiponectin was inversely associated with PDAC risk [110]. A case-control study showed no association of adiponectin with PDAC risk overall; however, higher adiponectin levels were associated with a reduction in PDAC risk among never smokers [111]. An influence of smoking on the risk of adiponectin on PDAC risk has been reported [112]. However, a Mendelian randomization study did not find an association of adiponectin with PDAC risk [93]. Furthermore, other studies reported higher adiponectin levels in patients PDAC [113-115]. However, in these studies, adiponectin levels were measured at the time of diagnosis or treatment of PDAC and the true effect of adiponectin on PDAC risk may have been obscured. In preclinical murine studies, an AdipoR agonist (AdipoRon) decreased the growth of PDAC xenografts [116,117]. Conversely, deficiency or knockdown of adiponectin receptors markedly promoted PDAC xenograft growth $[118,119]$. Interestingly, a recent xenograft study showed that AdipoRon failed to suppress PDAC growth in mice with DIO, while it suppressed tumor growth in lean mice [120]. Taken together, a link between adiponectin and PDAC risk is not conclusively demonstrated by available epidemiologic studies. Preclinical evidence provides a stronger support of a role of adiponectin in PDAC therapy. Further, carefully designed studies are clearly needed to answer the question whether low adiponectin levels as seen in obese subjects causally increase the risk of developing PDAC.

\subsubsection{Lipocalin-2}

Another interesting molecule that may provide a link between obesity and PDAC is lipocalin-2 (LCN2). LCN2, also known as neutrophil gelatinase-associated lipocalin (NGAL), is a $25 \mathrm{kDa}$ protein expressed and secreted by various cell types, which belongs to 
a large group of small extracellular proteins with a variety of biological functions, including iron homeostasis, inflammation, innate immunity, and energy metabolism [121-124]. LCN2 is also considered an adipokine. It is secreted from adipocytes and its production is highly regulated by metabolic stress, inflammatory cytokines, and nutrient signals [124]. Elevated LCN2 levels are typically found in obese humans and mouse models of obesity $[125,126]$. LCN2 has been implicated in the pathogenesis of various pancreatic diseases, including PDAC, acute and chronic pancreatitis, and T2DM [127]. LCN2 is upregulated in PDAC mouse models, correlates to decreased food intake, and its absence protects from tumor cachexia, presumably via a type 4 melanocortin receptor-mediated mechanism [128]. Increased LCN2 expression has been found in human PanINs and PDAC [129-131]. However, preclinical studies reported contradictory, pro- and anti-tumor functions of LCN2 in PDAC [132-134]. Using Kras G12D;Ela-CreERT;Lcn2 ${ }^{-/-}$mice (whole body deletion of LCN2) Cruz-Monserrate and colleagues showed that lack of LCN2 prevents weight gain and obesity when fed a high-fat diet [135]. This was associated with reduced pancreatic fibroinflammation, PanIN formation, and prolonged survival, indicating a tumor-promoting role of LCN2 in PDAC [135]. However, it is not clear whether the reduced tumor growth in $\mathrm{Kras}^{\mathrm{G} 12 \mathrm{D}}$;Ela-CreERT;Lcn2 ${ }^{-/-}$mice was directly due to the lack of LCN2 effects on the pancreas or indirectly to the reduced weight gain (anti-obesity effects). Further orthotopic syngeneic studies showed that lack of LCN2 in the host significantly diminished pancreatic fibrosis and inflammation and attenuated growth of (LCN2 expressing) PDAC cells [135], pointing to the importance of paracrine LCN2 (rather than autocrine) effects in PDAC. Taken together, it is conceivable that elevated LCN2 during obesity is a driver of PDAC development and progression, although further studies are clearly needed to cement that hypothesis.

\subsubsection{FGF21}

As a novel fibroblast growth factor (FGF) family member identified in 2000 [136], FGF21, has emerged as an important regulator and orchestrator of glucose and lipid metabolism and energy homeostasis $[137,138]$ with the potential to treat obesity, T2DM, and meta-inflammation [139-142]. FGF21 is considered a "master sensitizer" of metabolic hormonal signals [143]. Circulating FGF21 levels are elevated in diabetic and obese subjects [144] and administration of FGF21 has been shown to enhance insulin sensitivity and reverses obesity by increasing energy expenditure $[145,146]$. On target cells, FGF21 binds to and activates a receptor complex of FGF receptor 1c (FGFR1c) and its co-receptor $\beta$-Klotho (KLB); however, little is known about the downstream intracellular signaling events [143]. Exciting recent studies implicate FGF21 in obesity-promoted PDAC [147-149]. Lu and colleagues reported that FGF21, its target receptor FGF receptor 1 (FGFR1), and its coreceptor $\beta$-Klotho (KLB) were expressed in normal pancreatic acinar cells and showed that FGF21 levels were decreased downstream of oncogenic Kras [147]. Administration of recombinant human FGF21 to Kras ${ }^{G 12 D}$;Ela-CreERT mice fed a high-fat diet attenuated pancreatic and systemic inflammation, suppressed PanIN formation and PDAC development, and prolonged the survival of $\mathrm{Kras}^{\mathrm{G} 12 \mathrm{D} /+}$ mice [147]. The authors concluded that downregulation of pancreatic FGF21 by oncogenic Kras renders the pancreas vulnerable to an obesogenic high-fat diet, leading to enhanced inflammation and the development of PDAC. It is relevant that acute and chronic pancreatitis, a condition that increases PDAC incidence in preclinical models and human patients, has been also associated with a marked decrease of FGF21 in the pancreas [150].

\subsubsection{Wnt5a}

Recent studies have demonstrated that the pro-inflammatory adipokine wingless-type mouse mammary tumor virus integration site family member $5 \mathrm{~A}$ (Wnt5a), together with the anti-inflammatory secreted frizzled-related protein 5 (Sfrp5), which both signal via the non-canonical Wnt pathway, play a key role in the pathogenesis of obesity and its metabolic complications [151,152]. The circulating levels of Wnt5a and its expression in VAT 
are increased in obesity [152,153], contributing to systemic and local inflammation [154]. Furthermore, overexpression of Wnt5a has been reported in human PDAC [155] and has a profound impact on the PDAC microenvironment [156]. The link between adipose tissue, Wnt5a, and PDAC has gained enormous significance, as Wnt5a has been shown to positively correlate with Yes-associated protein (YAP) activity (see below) in human PDAC [157]. Wnt5a leads to YAP activation, which drives the aggressive squamous subtype of PDAC, which is YAP dependent but Kras independent [157]. We postulate that elevated levels of Wnt5a during obesity (released from the VAT) may promote the development and growth of the aggressive squamous subtype of PDAC through YAP-mediated mechanisms, although further studies are needed to confirm this model.

\subsubsection{Intrapancreatic Fat}

While the link between general and visceral adiposity to PDAC is well established, studies on the functional significance of intrapancreatic fat on pancreatic carcinogenesis and cancer promotion are very scarce and just recently have attracted increased attention. While the presence of fat in the pancreas has been first described almost a century ago [158] and thought of as a bystander of several underlying diseases, there is now increased recognition that intrapancreatic fat deposition, variably also called pancreatic steatosis or fatty pancreas disease, has a role in T2DM, pancreatitis, and pancreatic cancer [159-162]. While several histological studies have demonstrated a small amount of intrapancreatic fat in the majority of normal pancreata $[163,164]$, excess intrapancreatic fat is now discussed to be important in the development of endocrine and exocrine pancreatic diseases. Excess intrapancreatic fat can originate from the formation and expansion of intra- and/or interlobular fat [165], which are not exclusive but can be present simultaneously in the same organ. Intracellular fat droplets (positive for adipose differentiation-related protein (ADFP)) have been found in pancreatic endocrine cells $[166,167]$ and acinar cells after high-fat diets $[168,169]$. Intraand interlobular perilipin-positive adipocytes have been detected in the human and mouse pancreas, which was increased in mice after a high-fat diet $[80,169]$. The source of these adipocytes may be mesenchymal stem cells in the pancreatic stroma, which can differentiate into adipocytes [170]. AT-derived stem or progenitor cells have been reported to be able to home to the tumor stroma promoting cancer progression [171,172]. During obesity, AT-derived progenitor cells, which are elevated and mobilized in obesity, may differentiate into adipocytes in the pancreatic microenvironment. The importance of the visceral mesothelium, which also covers the pancreas, in pancreatic cancer biology and as a source of adipocytes has been reported [173-176]. However, a recent study refutes mesothelial cells as a source of adipocytes in mice [177]. In addition, it has been reported that an acinarto-adipocyte transdifferentiation program exists, possibly driven by inflammation [178]. Finally, pancreatic stellate cells have been shown in vitro to be able to transdifferentiate into adipocyte-like cells [179]. Our knowledge of the importance of intrapancreatic fat for the development and progression of pancreatic cancer is still in its infancy, and preclinical studies are necessary to illuminate its functional significance. It is conceivable that the formation and expansion of intrapancreatic fat (intra- and/or interlobular) that may be seen during obesity has a profound paracrine metabolic and proliferative effect on transformed pancreatic epithelial cells via local secretion of adipokines and other adipose-derived inflammatory cytokines. In addition, intrapancreatic adipocytes may also be an important source of free fatty acids, which can be used by malignant cells as fuel and for membrane synthesis [180] as well as paracrine signals.

\subsection{Insulin and Insulin-Like Growth Factor-1}

Patients with long-standing T2DM have an increased risk of PDAC [13,14,181,182]. In addition, T2DM is often associated with obesity, which by itself also promotes PDAC development (see above). Patients with T2DM and obesity are often characterized by long periods of elevated intrapancreatic insulin levels caused by the pancreatic $\beta$-cells trying to overcome the insulin resistance present in T2DM and obesity to maintain glucose 
homeostasis. Elevated levels of insulin, particularly intrapancreatic, can reach pancreatic acinar and ductal cells adjacent to pancreatic islets via the intrapancreatic portal circulation, activate insulin and IGF-1 receptors present on these cells, and may thus conceivably contribute to the PDAC growth [182]. The importance of insulin is underscored by mouse models of PDAC. For example, KC mice subjected to DIO consistently developed hyperinsulinemia and elevated levels of IGF-1 [42-44,94]. Furthermore, the anti-diabetic drug metformin significantly suppressed PDAC development in KC mice with DIO, which was associated with a normalization of the hyperinsulinemia [60]. In vitro experiments have clearly demonstrated the proliferative action of insulin on PDAC cells [183-188]. A crosstalk between insulin/IGF-1 receptors and G protein-coupled receptor signaling systems has been identified that converges on the mechanistic target of rapamycin (mTOR), which is inhibited by metformin $[184-187,189]$. Furthermore, the crosstalk between the insulin receptor and GPCRs has been shown to potently stimulate YAP through PI3K and protein kinase D in PDAC cells [183]. YAP and its paralogue transcriptional co-activator with PDZ-binding motif (TAZ), as major downstream effectors of the Hippo pathway, have recently gained enormous interest as critical molecules in PDAC formation and progression [157,190-197]. Interestingly, the expression of YAP and TAZ in the pancreas is increased in $\mathrm{KC}$ mice with DIO, which is downregulated by metformin [60]. Taken together, it has been conclusively shown that insulin receptor and GPCRs signaling pathways stimulate PDAC cell proliferation by converging on mTOR. In obesity, elevated levels of insulin/IGF-1 and gastrointestinal peptides that act via their cognate GPCRs, e.g., neurotensin [198], enhance the crosstalk between insulin receptor and GPCR signaling pathways, leading to increased cellular proliferation. Targeting this insulin receptor/GPCR crosstalk with the antidiabetic drug metformin may have potent beneficial effects on PDAC development [199]. In addition to the importance of hyperinsulinemia, elevated glucose levels and advanced glycation end products (AGE) may also play an important role. In this context, the receptor for AGEs (RAGE) has been shown to be a tumor promoting factor in PDAC and to orchestrate the interplay between metabolic diseases, inflammation, and cancer [200-202].

\subsection{Gut Microbiome}

Human studies and animal models have demonstrated that the gut microbiota is altered in obesity [203-205]. Generally, the microbial diversity as seen in healthy individuals is decreased in obese subjects. In particular, an abundance of Firmicutes (increase in the Firmicutes:Bacteroidetes ratio) was found in mice with diet-induced and genetic obesity [206-208]. Additionally, animal studies provide evidence that changes in the gut microflora are causally linked to the development of obesity and T2DM [205,209,210]. Furthermore, there is strong evidence that altered gut microbiota are critical for the development of colorectal cancer [211]. In another study, dietary or genetic obesity induced changes in the gut microbiota, which facilitated the development of hepatocellular carcinoma in mice through an increase of deoxycholic acid [212]. The gut microbiome has been implicated in PDAC as well [213-215]. Importantly, the presence and significance of an intrapancreatic, intratumoral microbiome that crosstalks with the gut microbiome has been reported [216-218]. In addition to the microbiome, the fungal mycobiome has recently been shown to promote pancreatic carcinogenesis [219]. Our own studies have shown that oral administration of metformin to KC mice fed an obesogenic high-fat diet normalized the high diet-induced gut dysbiosis [220]. We found that oral administration of metformin to obese KC mice lowered the abundance of the genus Clostridium sensu stricto and significantly increased the levels of Akkermansia [220]. Akkermansia muciniphila, an intestinal symbiotic bacterium, plays an important role in maintaining a functioning gut barrier [221-223]. Data from human studies confirmed that the abundance of Akkermansia muciniphila correlates to a lower incidence of obesity and other metabolic diseases $[224,225]$.

Changes in the gut microbiome, caused by genetic, environmental, or nutritional factors, are thought to influence the development of metabolic diseases and cancer by 
several mechanisms. These include microbiota-derived metabolites, e.g., short-chain fatty acids (mainly acetate, propionate, and butyrate), activation of intestinal GPCRs, or translocation of bacteria or bacterial components, e.g., lipopolysaccharide (LPS), enabled by an increase in gut permeability, leading to a systemic pro-inflammatory state [205]. It is well known that obesity is associated with elevated circulating LPS levels (metabolic endotoxemia) [226-228]. Animal models showed that obesity-associated metabolic endotoxemia induced AT inflammation through an LPS/toll-like receptor 4 (TLR4)-mediated mechanism [207,228,229]. Microbial alterations in PDAC featured an increase of certain pathogens and LPS-producing bacteria [230]. Although, to our knowledge, no studies have been published that directly measured LPS levels in the pancreas of obese subjects with PDAC, other reports using obese rats with deficiency in TLR4 have implicated an important role of LPS for the pancreatic $\beta$-cell function in [231]. Furthermore, exogenous administration of LPS to mice with oncogenic Kras expression in pancreatic acinar cells led to chronic pancreatitis and neoplastic PanIN formation [58]. In addition, besides direct action of LPS on PDAC cells [232], elevated LPS levels during obesity can also induce a shift of intrapancreatic resident macrophages and/or recruited monocytes into pro-inflammatory M1-like macrophages, which may promote PanIN development [80].

\section{Conclusions}

Human and preclinical mouse studies have convincingly demonstrated that obesity increases the risk of developing PDAC and promotes PDAC growth. Several mechanisms are generally discussed that underlie the obesity-PDAC connection. A central role is clearly played by adipose tissue and obesity-associated adipose tissue inflammation (Figure 2).

Soluble adipokines and other inflammatory mediators secreted by the adipose tissue (visceral and/or intrapancreatic) can reach the pancreas systemically and/or via paracrine mechanisms. These mediators can affect metabolism and growth of transformed pancreatic epithelial cells and shape the pancreatic microenvironment. Furthermore, neoplastic pancreatic cells themselves generate pro-tumorigenic factors downstream of oncogenic Kras, which may be augmented and positively reinforced by systemic and paracrine effects of the adipose tissue. Obesity-associated adipose tissue inflammation also plays a major role in creating insulin resistance with ensuing hyperinsulinemia. Elevated insulin levels, systemically and locally, are known as potent growth stimulating factors for transformed pancreatic epithelial cells. Obesity-associated gut dysbiosis may lead to the perturbation of the pancreatic microbiome, which may induce and exacerbate pancreatic inflammation and neoplastic development. In addition, gut dysbiosis as seen in obesity also leads to an impaired gut barrier function and subsequent metabolic endotoxemia, which is thought to be a critical factor in inducing adipose tissue inflammation. Given the central role of adipose tissue in linking obesity with PDAC risk and growth, strategies to target the adipose tissue seem to be of paramount importance to curtail the PDAC promoting actions of obesity. This may be achieved by interventions aimed at inhibiting or reducing obesity-associated adipose tissue inflammation in general or by targeting specific factors that mechanistically initiate and sustain the link between adipose tissue and pancreatic neoplastic cells. 


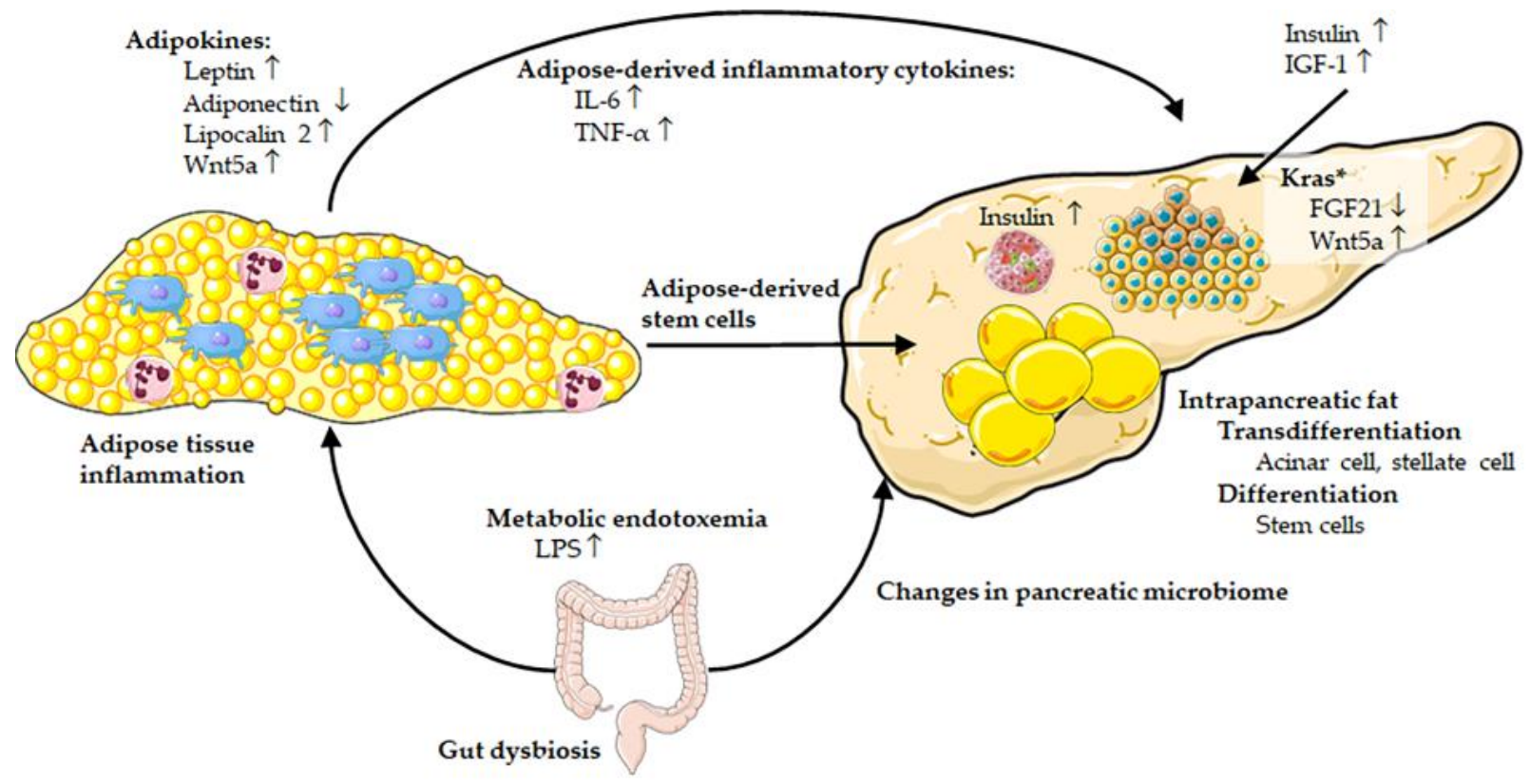

Figure 2. Schematic overview of the mechanisms linking obesity, adipose tissue, and pancreatic cancer as discussed in the main text. During obesity, inflamed (visceral) adipose tissue (adipocytes and resident/recruited immune cells) releases a variety of adipokines (e.g., increase in leptin, lipocalin 2, Wnt5a, and decrease in adiponectin) and adipose-derived inflammatory cytokines (e.g., IL-6 and TNF- $\alpha$ ) that may promote proliferation of transformed pancreatic epithelial cells. Obesity-associated gut dysbiosis may lead to metabolic endotoxemia (elevated LPS) that plays a role in adipose tissue inflammation and has direct effects on pancreatic cells. Obesity-associated changes of the gut microbiome may also induce or alter the pancreatic microbiome, which promotes cancer growth. Obesity-associated systemic hyperinsulinemia (and elevated IGF-1) as well as elevated intrapancreatic insulin levels (from pancreatic $\beta$-cells) can act as potent growth stimulatory factors for transformed (pre-)neoplastic pancreatic cells. Intrapancreatic adipocytes, either through differentiation of adipose-derived stem cells and/or transdifferentiation of acinar (or pancreatic stellate) cells, may also have a robust impact on pancreatic cancer cell proliferation and changes of the tumor microenvironment. Downstream of oncogenic Kras, the decrease in FGF21 (in transformed pancreatic cells) may render the pancreas susceptible to the pro-tumorigenic effects of obesity. Blue and purple cells within the adipose tissue illustrate various immune cells (e.g., neutrophils (purple) and macrophages (blue)). Yellow circles within the adipose tissue represent adipocytes. Partly created with Servier Medical Art.

Author Contributions: Writing—original draft preparation, G.E.; writing-review and editing, G.E. and E.R. Both authors have read and agreed to the published version of the manuscript.

Funding: Guido Eibl is supported by the National Institutes of Health, National Cancer Institute (P01CA236585), and the Hirshberg Foundation for Pancreatic Cancer Research. Enrique Rozengurt is supported by the National Institutes of Health, National Cancer Institute (P01CA236585), National Institute of Allergy and Infectious Diseases (R21AI156592), the Veterans Administration (I01BX003801), and the Hirshberg Foundation for Pancreatic Cancer Research.

Conflicts of Interest: The authors declare no conflict of interest.

\section{References}

1. Obesity and overweight. Available online: https://www.who.int/news-room/fact-sheets/detail/obesity-and-overweight (accessed on 1 August 2021).

2. Hales, C.M.; Carroll, M.D.; Fryar, C.D.; Ogden, C.L. Prevalence of Obesity and Severe Obesity Among Adults: United States, 2017-2018. NCHS Data Brief. 2020, 360, 1-8.

3. Lauby-Secretan, B.; Scoccianti, C.; Loomis, D.; Grosse, Y.; Bianchini, F.; Straif, K. International Agency for Research on Cancer Handbook Working, G. Body Fatness and Cancer-Viewpoint of the IARC Working Group. N. Engl. J. Med. 2016, 375, 794-798. [CrossRef]

4. Bluher, M. Obesity: Global epidemiology and pathogenesis. Nat. Rev. Endocrinol. 2019, 15, 288-298. [CrossRef]

5. Bray, G.A.; Kim, K.K.; Wilding, J.P.H.; World Obesity Federation. Obesity: A chronic relapsing progressive disease process. A position statement of the World Obesity Federation. Obes. Rev. 2017, 18, 715-723. [CrossRef] 
6. Siegel, R.L.; Miller, K.D.; Fuchs, H.E.; Jemal, A. Cancer Statistics, 2021. CA Cancer J. Clin. 2021, 71, 7-33. [CrossRef]

7. Siegel, R.L.; Miller, K.D.; Jemal, A. Cancer statistics, 2016. CA Cancer J. Clin. 2016, 66, 7-30. [CrossRef]

8. Rahib, L.; Smith, B.D.; Aizenberg, R.; Rosenzweig, A.B.; Fleshman, J.M.; Matrisian, L.M. Projecting cancer incidence and deaths to 2030: The unexpected burden of thyroid, liver, and pancreas cancers in the United States. Cancer Res. 2014, 74, $2913-2921$. [CrossRef]

9. Genkinger, J.M.; Kitahara, C.M.; Bernstein, L.; Berrington de Gonzalez, A.; Brotzman, M.; Elena, J.W.; Giles, G.G.; Hartge, P.; Singh, P.N.; Stolzenberg-Solomon, R.Z.; et al. Central adiposity, obesity during early adulthood, and pancreatic cancer mortality in a pooled analysis of cohort studies. Ann. Oncol. 2015, 26, 2257-2266. [CrossRef] [PubMed]

10. Preziosi, G.; Oben, J.A.; Fusai, G. Obesity and pancreatic cancer. Surg. Oncol. 2014, 23, 61-71. [CrossRef] [PubMed]

11. Bracci, P.M. Obesity and pancreatic cancer: Overview of epidemiologic evidence and biologic mechanisms. Mol. Carcinog. 2012, 51, 53-63. [CrossRef] [PubMed]

12. Aune, D.; Greenwood, D.C.; Chan, D.S.; Vieira, R.; Vieira, A.R.; Navarro Rosenblatt, D.A.; Cade, J.E.; Burley, V.J.; Norat, T. Body mass index, abdominal fatness and pancreatic cancer risk: A systematic review and non-linear dose-response meta-analysis of prospective studies. Ann. Oncol. 2012, 23, 843-852. [CrossRef] [PubMed]

13. Eibl, G.; Cruz-Monserrate, Z.; Korc, M.; Petrov, M.S.; Goodarzi, M.O.; Fisher, W.E.; Habtezion, A.; Lugea, A.; Pandol, S.J.; Hart, P.A.; et al. Diabetes Mellitus and Obesity as Risk Factors for Pancreatic Cancer. J. Acad. Nutr. Diet. 2018, 118, 555-567. [CrossRef] [PubMed]

14. Abbruzzese, J.L.; Andersen, D.K.; Borrebaeck, C.A.K.; Chari, S.T.; Costello, E.; Cruz-Monserrate, Z.; Eibl, G.; Engleman, E.G.; Fisher, W.E.; Habtezion, A.; et al. The Interface of Pancreatic Cancer with Diabetes, Obesity, and Inflammation: Research Gaps and Opportunities: Summary of a National Institute of Diabetes and Digestive and Kidney Diseases Workshop. Pancreas 2018, 47, 516-525. [CrossRef] [PubMed]

15. Islami, F.; Goding Sauer, A.; Miller, K.D.; Siegel, R.L.; Fedewa, S.A.; Jacobs, E.J.; McCullough, M.L.; Patel, A.V.; Ma, J.; Soerjomataram, I.; et al. Proportion and number of cancer cases and deaths attributable to potentially modifiable risk factors in the United States. CA Cancer J. Clin. 2018, 68, 31-54. [CrossRef]

16. Li, D.; Morris, J.S.; Liu, J.; Hassan, M.M.; Day, R.S.; Bondy, M.L.; Abbruzzese, J.L. Body mass index and risk, age of onset, and survival in patients with pancreatic cancer. JAMA 2009, 301, 2553-2562. [CrossRef] [PubMed]

17. Nogueira, L.; Stolzenberg-Solomon, R.; Gamborg, M.; Sorensen, T.I.A.; Baker, J.L. Childhood body mass index and risk of adult pancreatic cancer. Curr. Dev. Nutr. 2017, 1, e001362. [CrossRef]

18. Fang, X.; Wang, X.; Song, Z.; Han, D.; Yin, X.; Liu, B.; Chen, L.; Zhang, R.; Lian, F.; Sui, X. Causal association of childhood obesity with cancer risk in adulthood: A Mendelian randomization study. Int. J. Cancer 2021, 149, 1421-1425. [CrossRef]

19. Zohar, L.; Rottenberg, Y.; Twig, G.; Katz, L.; Leiba, A.; Derazne, E.; Tzur, D.; Eizenstein, S.; Keinan-Boker, L.; Afek, A.; et al. Adolescent overweight and obesity and the risk for pancreatic cancer among men and women: A nationwide study of 1.79 million Israeli adolescents. Cancer 2019, 125, 118-126. [CrossRef]

20. Hidayat, K.; Du, X.; Shi, B.M. Body fatness at a young age and risks of eight types of cancer: Systematic review and meta-analysis of observational studies. Obes. Rev. 2018, 19, 1385-1394. [CrossRef]

21. Petrelli, F.; Cortellini, A.; Indini, A.; Tomasello, G.; Ghidini, M.; Nigro, O.; Salati, M.; Dottorini, L.; Iaculli, A.; Varricchio, A.; et al. Association of Obesity with Survival Outcomes in Patients with Cancer: A Systematic Review and Meta-analysis. JAMA Netw. Open 2021, 4, e213520. [CrossRef]

22. Park, Y.; Peterson, L.L.; Colditz, G.A. The Plausibility of Obesity Paradox in Cancer-Point. Cancer Res. 2018, 78, 1898-1903. [CrossRef] [PubMed]

23. Wang, Z.; Aguilar, E.G.; Luna, J.I.; Dunai, C.; Khuat, L.T.; Le, C.T.; Mirsoian, A.; Minnar, C.M.; Stoffel, K.M.; Sturgill, I.R.; et al. Paradoxical effects of obesity on T cell function during tumor progression and PD-1 checkpoint blockade. Nat. Med. 2019, 25, 141-151. [CrossRef] [PubMed]

24. Cespedes Feliciano, E.M.; Kroenke, C.H.; Caan, B.J. The Obesity Paradox in Cancer: How Important Is Muscle? Annu. Rev. Nutr. 2018, 38, 357-379. [CrossRef] [PubMed]

25. Almoguera, C.; Shibata, D.; Forrester, K.; Martin, J.; Arnheim, N.; Perucho, M. Most human carcinomas of the exocrine pancreas contain mutant c-K-ras genes. Cell 1988, 53, 549-554. [CrossRef]

26. Whitcomb, D.C.; Shelton, C.A.; Brand, R.E. Genetics and Genetic Testing in Pancreatic Cancer. Gastroenterology 2015, 149, 1252-1264.e4. [CrossRef]

27. Hruban, R.H.; Adsay, N.V.; Albores-Saavedra, J.; Anver, M.R.; Biankin, A.V.; Boivin, G.P.; Furth, E.E.; Furukawa, T.; Klein, A.; Klimstra, D.S.; et al. Pathology of genetically engineered mouse models of pancreatic exocrine cancer: Consensus report and recommendations. Cancer Res. 2006, 66, 95-106. [CrossRef]

28. Hruban, R.H.; Rustgi, A.K.; Brentnall, T.A.; Tempero, M.A.; Wright, C.V.; Tuveson, D.A. Pancreatic cancer in mice and man: The Penn Workshop 2004. Cancer Res. 2006, 66, 14-17. [CrossRef]

29. Hingorani, S.R.; Petricoin, E.F.; Maitra, A.; Rajapakse, V.; King, C.; Jacobetz, M.A.; Ross, S.; Conrads, T.P.; Veenstra, T.D.; Hitt, B.A.; et al. Preinvasive and invasive ductal pancreatic cancer and its early detection in the mouse. Cancer Cell 2003, 4, 437-450. [CrossRef] 
30. Morton, J.P.; Jamieson, N.B.; Karim, S.A.; Athineos, D.; Ridgway, R.A.; Nixon, C.; McKay, C.J.; Carter, R.; Brunton, V.G.; Frame, M.C.; et al. LKB1 haploinsufficiency cooperates with Kras to promote pancreatic cancer through suppression of p21-dependent growth arrest. Gastroenterology 2010, 139, 586-597. [CrossRef]

31. Morton, J.P.; Timpson, P.; Karim, S.A.; Ridgway, R.A.; Athineos, D.; Doyle, B.; Jamieson, N.B.; Oien, K.A.; Lowy, A.M.; Brunton, V.G.; et al. Mutant p53 drives metastasis and overcomes growth arrest/senescence in pancreatic cancer. Proc. Natl. Acad. Sci. USA 2010, 107, 246-251. [CrossRef]

32. Hingorani, S.R.; Wang, L.; Multani, A.S.; Combs, C.; Deramaudt, T.B.; Hruban, R.H.; Rustgi, A.K.; Chang, S.; Tuveson, D.A. Trp53R172H and KrasG12D cooperate to promote chromosomal instability and widely metastatic pancreatic ductal adenocarcinoma in mice. Cancer Cell 2005, 7, 469-483. [CrossRef]

33. Collins, M.A.; Bednar, F.; Zhang, Y.; Brisset, J.C.; Galban, S.; Galban, C.J.; Rakshit, S.; Flannagan, K.S.; Adsay, N.V.; Pasca di Magliano, M. Oncogenic Kras is required for both the initiation and maintenance of pancreatic cancer in mice. J. Clin. Investig. 2012, 122, 639-653. [CrossRef]

34. Collins, M.A.; Brisset, J.C.; Zhang, Y.; Bednar, F.; Pierre, J.; Heist, K.A.; Galban, C.J.; Galban, S.; di Magliano, M.P. Metastatic pancreatic cancer is dependent on oncogenic Kras in mice. PLoS ONE 2012, 7, e49707. [CrossRef]

35. Ying, H.; Kimmelman, A.C.; Lyssiotis, C.A.; Hua, S.; Chu, G.C.; Fletcher-Sananikone, E.; Locasale, J.W.; Son, J.; Zhang, H.; Coloff, J.L.; et al. Oncogenic Kras maintains pancreatic tumors through regulation of anabolic glucose metabolism. Cell 2012, 149, 656-670. [CrossRef]

36. Habbe, N.; Shi, G.; Meguid, R.A.; Fendrich, V.; Esni, F.; Chen, H.; Feldmann, G.; Stoffers, D.A.; Konieczny, S.F.; Leach, S.D.; et al. Spontaneous induction of murine pancreatic intraepithelial neoplasia (mPanIN) by acinar cell targeting of oncogenic Kras in adult mice. Proc. Natl. Acad. Sci. USA 2008, 105, 18913-18918. [CrossRef]

37. Philip, B.; Roland, C.L.; Daniluk, J.; Liu, Y.; Chatterjee, D.; Gomez, S.B.; Ji, B.; Huang, H.; Wang, H.; Fleming, J.B.; et al. A high-fat diet activates oncogenic Kras and COX2 to induce development of pancreatic ductal adenocarcinoma in mice. Gastroenterology 2013, 145, 1449-1458. [CrossRef]

38. Desai, B.M.; Oliver-Krasinski, J.; De Leon, D.D.; Farzad, C.; Hong, N.; Leach, S.D.; Stoffers, D.A. Preexisting pancreatic acinar cells contribute to acinar cell, but not islet beta cell, regeneration. J. Clin. Investig. 2007, 117, 971-977. [CrossRef]

39. Means, A.L.; Xu, Y.; Zhao, A.; Ray, K.C.; Gu, G. A CK19(CreERT) knockin mouse line allows for conditional DNA recombination in epithelial cells in multiple endodermal organs. Genesis 2008, 46, 318-323. [CrossRef]

40. Kopp, J.L.; von Figura, G.; Mayes, E.; Liu, F.F.; Dubois, C.L.; Morris IV, J.P.; Pan, F.C.; Akiyama, H.; Wright, C.V.; Jensen, K.; et al. Identification of Sox9-dependent acinar-to-ductal reprogramming as the principal mechanism for initiation of pancreatic ductal adenocarcinoma. Cancer Cell 2012, 22, 737-750. [CrossRef]

41. Ray, K.C.; Bell, K.M.; Yan, J.; Gu, G.; Chung, C.H.; Washington, M.K.; Means, A.L. Epithelial tissues have varying degrees of susceptibility to Kras(G12D)-initiated tumorigenesis in a mouse model. PLoS ONE 2011, 6, e16786. [CrossRef]

42. Chang, H.H.; Moro, A.; Takakura, K.; Su, H.Y.; Mo, A.; Nakanishi, M.; Waldron, R.T.; French, S.W.; Dawson, D.W.; Hines, O.J.; et al. Incidence of pancreatic cancer is dramatically increased by a high fat, high calorie diet in KrasG12D mice. PLoS ONE 2017, 12, e0184455. [CrossRef]

43. Dawson, D.W.; Hertzer, K.; Moro, A.; Donald, G.; Chang, H.H.; Go, V.L.; Pandol, S.J.; Lugea, A.; Gukovskaya, A.S.; Li, G.; et al. High-fat, high-calorie diet promotes early pancreatic neoplasia in the conditional KrasG12D mouse model. Cancer Prev. Res. 2013, 6, 1064-1073. [CrossRef] [PubMed]

44. Lashinger, L.M.; Harrison, L.M.; Rasmussen, A.J.; Logsdon, C.D.; Fischer, S.M.; McArthur, M.J.; Hursting, S.D. Dietary energy balance modulation of Kras- and Ink4a/Arf+/ --driven pancreatic cancer: The role of insulin-like growth factor-I. Cancer Prev. Res. 2013, 6, 1046-1055. [CrossRef] [PubMed]

45. Funahashi, H.; Satake, M.; Dawson, D.; Huynh, N.A.; Reber, H.A.; Hines, O.J.; Eibl, G. Delayed progression of pancreatic intraepithelial neoplasia in a conditional Kras(G12D) mouse model by a selective cyclooxygenase-2 inhibitor. Cancer Res. 2007, 67, 7068-7071. [CrossRef] [PubMed]

46. Chung, K.M.; Singh, J.; Lawres, L.; Dorans, K.J.; Garcia, C.; Burkhardt, D.B.; Robbins, R.; Bhutkar, A.; Cardone, R.; Zhao, X.; et al. Endocrine-Exocrine Signaling Drives Obesity-Associated Pancreatic Ductal Adenocarcinoma. Cell 2020, 181, 832-847.e18. [CrossRef] [PubMed]

47. Conroy, M.J.; Dunne, M.R.; Donohoe, C.L.; Reynolds, J.V. Obesity-associated cancer: An immunological perspective. Proc. Nutr. Soc. 2016, 75, 125-138. [CrossRef]

48. Deng, T.; Lyon, C.J.; Bergin, S.; Caligiuri, M.A.; Hsueh, W.A. Obesity, Inflammation, and Cancer. Annu. Rev. Pathol. 2016, 11, 421-449. [CrossRef]

49. Kaaks, R.; Kuhn, T. Epidemiology: Obesity and cancer-the evidence is fattening up. Nat. Rev. Endocrinol. 2014, 10, 644-645. [CrossRef]

50. Kant, P.; Hull, M.A. Excess body weight and obesity-the link with gastrointestinal and hepatobiliary cancer. Nat. Rev. Gastroenterol. Hepatol. 2011, 8, 224-238. [CrossRef]

51. Park, J.; Morley, T.S.; Kim, M.; Clegg, D.J.; Scherer, P.E. Obesity and cancer-mechanisms underlying tumour progression and recurrence. Nat. Rev. Endocrinol. 2014, 10, 455-465. [CrossRef]

52. Kanda, M.; Matthaei, H.; Wu, J.; Hong, S.M.; Yu, J.; Borges, M.; Hruban, R.H.; Maitra, A.; Kinzler, K.; Vogelstein, B.; et al. Presence of somatic mutations in most early-stage pancreatic intraepithelial neoplasia. Gastroenterology 2012, 142, 730-733.e9. [CrossRef] 
53. Jones, S.; Zhang, X.; Parsons, D.W.; Lin, J.C.; Leary, R.J.; Angenendt, P.; Mankoo, P.; Carter, H.; Kamiyama, H.; Jimeno, A.; et al. Core signaling pathways in human pancreatic cancers revealed by global genomic analyses. Science 2008, 321, $1801-1806$. [CrossRef]

54. Biankin, A.V.; Waddell, N.; Kassahn, K.S.; Gingras, M.C.; Muthuswamy, L.B.; Johns, A.L.; Miller, D.K.; Wilson, P.J.; Patch, A.M.; $\mathrm{Wu}$, J.; et al. Pancreatic cancer genomes reveal aberrations in axon guidance pathway genes. Nature 2012, 491, 399-405. [CrossRef] [PubMed]

55. Notta, F.; Hahn, S.A.; Real, F.X. A genetic roadmap of pancreatic cancer: Still evolving. Gut 2017, 66, 2170-2178. [CrossRef] [PubMed]

56. Huang, H.; Daniluk, J.; Liu, Y.; Chu, J.; Li, Z.; Ji, B.; Logsdon, C.D. Oncogenic K-Ras requires activation for enhanced activity. Oncogene 2014, 33, 532-535. [CrossRef] [PubMed]

57. Logsdon, C.D.; Lu, W. The Significance of Ras Activity in Pancreatic Cancer Initiation. Int. J. Biol. Sci. 2016, 12, 338-346. [CrossRef]

58. Daniluk, J.; Liu, Y.; Deng, D.; Chu, J.; Huang, H.; Gaiser, S.; Cruz-Monserrate, Z.; Wang, H.; Ji, B.; Logsdon, C.D. An NF-kappaB pathway-mediated positive feedback loop amplifies Ras activity to pathological levels in mice. J. Clin. Investig. 2012, 122, 1519-1528. [CrossRef] [PubMed]

59. Kano, Y.; Gebregiworgis, T.; Marshall, C.B.; Radulovich, N.; Poon, B.P.K.; St-Germain, J.; Cook, J.D.; Valencia-Sama, I.; Grant, B.M.M.; Herrera, S.G.; et al. Tyrosyl phosphorylation of KRAS stalls GTPase cycle via alteration of switch I and II conformation. Nat. Commun. 2019, 10, 224. [CrossRef]

60. Chang, H.H.; Moro, A.; Chou, C.E.N.; Dawson, D.W.; French, S.; Schmidt, A.I.; Sinnett-Smith, J.; Hao, F.; Hines, O.J.; Eibl, G.; et al. Metformin Decreases the Incidence of Pancreatic Ductal Adenocarcinoma Promoted by Diet-induced Obesity in the Conditional KrasG12D Mouse Model. Sci. Rep. 2018, 8, 5899. [CrossRef] [PubMed]

61. Trayhurn, P.; Wood, I.S. Adipokines: Inflammation and the pleiotropic role of white adipose tissue. Br. J. Nutr. 2004, 92, 347-355. [CrossRef]

62. Ouchi, N.; Parker, J.L.; Lugus, J.J.; Walsh, K. Adipokines in inflammation and metabolic disease. Nat. Rev. Immunol. 2011, 11, 85-97. [CrossRef]

63. Park, J.; Euhus, D.M.; Scherer, P.E. Paracrine and endocrine effects of adipose tissue on cancer development and progression. Endocr. Rev. 2011, 32, 550-570. [CrossRef] [PubMed]

64. Quail, D.F.; Dannenberg, A.J. The obese adipose tissue microenvironment in cancer development and progression. Nat. Rev. Endocrinol. 2019, 15, 139-154. [CrossRef] [PubMed]

65. Crewe, C.; Scherer, P.E. Intercellular and interorgan crosstalk through adipocyte extracellular vesicles. Rev. Endocr. Metab. Disord. 2021. [CrossRef]

66. Gesmundo, I.; Pardini, B.; Gargantini, E.; Gamba, G.; Birolo, G.; Fanciulli, A.; Banfi, D.; Congiusta, N.; Favaro, E.; Deregibus, M.C.; et al. Adipocyte-derived extracellular vesicles regulate survival and function of pancreatic beta cells. JCI Insight 2021, 6, e141962. [CrossRef] [PubMed]

67. Annett, S.; Moore, G.; Robson, T. Obesity and Cancer Metastasis: Molecular and Translational Perspectives. Cancers 2020, $12,3798$. [CrossRef]

68. Crewe, C.; Funcke, J.B.; Li, S.; Joffin, N.; Gliniak, C.M.; Ghaben, A.L.; An, Y.A.; Sadek, H.A.; Gordillo, R.; Akgul, Y.; et al. Extracellular vesicle-based interorgan transport of mitochondria from energetically stressed adipocytes. Cell Metab. 2021, 33, 1853-1868.e11. [CrossRef]

69. Kusminski, C.M.; Bickel, P.E.; Scherer, P.E. Targeting adipose tissue in the treatment of obesity-associated diabetes. Nat. Rev. Drug Discov. 2016, 15, 639-660. [CrossRef]

70. Lysaght, J.; van der Stok, E.P.; Allott, E.H.; Casey, R.; Donohoe, C.L.; Howard, J.M.; McGarrigle, S.A.; Ravi, N.; Reynolds, J.V.; Pidgeon, G.P. Pro-inflammatory and tumour proliferative properties of excess visceral adipose tissue. Cancer Lett. 2011, 312, 62-72. [CrossRef] [PubMed]

71. Tchkonia, T.; Thomou, T.; Zhu, Y.; Karagiannides, I.; Pothoulakis, C.; Jensen, M.D.; Kirkland, J.L. Mechanisms and metabolic implications of regional differences among fat depots. Cell Metab. 2013, 17, 644-656. [CrossRef]

72. Kwon, H.; Kim, D.; Kim, J.S. Body Fat Distribution and the Risk of Incident Metabolic Syndrome: A Longitudinal Cohort Study. Sci. Rep. 2017, 7, 10955. [CrossRef] [PubMed]

73. Kwee, T.C.; Kwee, R.M. Abdominal adiposity and risk of pancreatic cancer. Pancreas 2007, 35, 285-286. [CrossRef] [PubMed]

74. Rebours, V.; Gaujoux, S.; d'Assignies, G.; Sauvanet, A.; Ruszniewski, P.; Levy, P.; Paradis, V.; Bedossa, P.; Couvelard, A. Obesity and Fatty Pancreatic Infiltration Are Risk Factors for Pancreatic Precancerous Lesions (PanIN). Clin. Cancer Res. 2015, 21, 3522-3528. [CrossRef] [PubMed]

75. Hertzer, K.M.; Xu, M.; Moro, A.; Dawson, D.W.; Du, L.; Li, G.; Chang, H.H.; Stark, A.P.; Jung, X.; Hines, O.J.; et al. Robust Early Inflammation of the Peripancreatic Visceral Adipose Tissue During Diet-Induced Obesity in the KrasG12D Model of Pancreatic Cancer. Pancreas 2016, 45, 458-465. [CrossRef] [PubMed]

76. Hotamisligil, G.S. Inflammation and metabolic disorders. Nature 2006, 444, 860-867. [CrossRef]

77. Johnson, A.R.; Milner, J.J.; Makowski, L. The inflammation highway: Metabolism accelerates inflammatory traffic in obesity. Immunol. Rev. 2012, 249, 218-238. [CrossRef]

78. Wensveen, F.M.; Valentic, S.; Sestan, M.; Turk Wensveen, T.; Polic, B. The "Big Bang" in obese fat: Events initiating obesity-induced adipose tissue inflammation. Eur. J. Immunol. 2015, 45, 2446-2456. [CrossRef] 
79. Lumeng, C.N.; Bodzin, J.L.; Saltiel, A.R. Obesity induces a phenotypic switch in adipose tissue macrophage polarization. J. Clin. Investig. 2007, 117, 175-184. [CrossRef]

80. Teper, Y.; Eibl, G. Pancreatic Macrophages: Critical Players in Obesity-Promoted Pancreatic Cancer. Cancers 2020, $12,1946$. [CrossRef]

81. Dey, P.; Li, J.; Zhang, J.; Chaurasiya, S.; Strom, A.; Wang, H.; Liao, W.T.; Cavallaro, F.; Denz, P.; Bernard, V.; et al. Oncogenic KRAS-Driven Metabolic Reprogramming in Pancreatic Cancer Cells Utilizes Cytokines from the Tumor Microenvironment. Cancer Discov. 2020, 10, 608-625. [CrossRef]

82. Zhang, Y.; Proenca, R.; Maffei, M.; Barone, M.; Leopold, L.; Friedman, J.M. Positional cloning of the mouse obese gene and its human homologue. Nature 1994, 372, 425-432. [CrossRef]

83. Gorska, E.; Popko, K.; Stelmaszczyk-Emmel, A.; Ciepiela, O.; Kucharska, A.; Wasik, M. Leptin receptors. Eur. J. Med. Res. 2010, 15 (Suppl. 2), 50-54. [CrossRef] [PubMed]

84. Tartaglia, L.A.; Dembski, M.; Weng, X.; Deng, N.; Culpepper, J.; Devos, R.; Richards, G.J.; Campfield, L.A.; Clark, F.T.; Deeds, J.; et al. Identification and expression cloning of a leptin receptor, OB-R. Cell 1995, 83, 1263-1271. [CrossRef]

85. Huang, L.; Li, C. Leptin: A multifunctional hormone. Cell Res. 2000, 10, 81-92. [CrossRef]

86. Friedman, J.M.; Halaas, J.L. Leptin and the regulation of body weight in mammals. Nature 1998, 395, 763-770. [CrossRef] [PubMed]

87. Conde, J.; Scotece, M.; Gomez, R.; Lopez, V.; Gomez-Reino, J.J.; Lago, F.; Gualillo, O. Adipokines: Biofactors from white adipose tissue. A complex hub among inflammation, metabolism, and immunity. Biofactors 2011, 37, 413-420. [CrossRef]

88. Izquierdo, A.G.; Crujeiras, A.B.; Casanueva, F.F.; Carreira, M.C. Leptin, Obesity, and Leptin Resistance: Where Are We 25 Years Later? Nutrients 2019, 11, 2704. [CrossRef] [PubMed]

89. Considine, R.V.; Sinha, M.K.; Heiman, M.L.; Kriauciunas, A.; Stephens, T.W.; Nyce, M.R.; Ohannesian, J.P.; Marco, C.C.; McKee, L.J.; Bauer, T.L.; et al. Serum immunoreactive-leptin concentrations in normal-weight and obese humans. N. Engl. J. Med. 1996, 334, 292-295. [CrossRef]

90. Friedman, J. The long road to leptin. J. Clin. Investig. 2016, 126, 4727-4734. [CrossRef]

91. Stolzenberg-Solomon, R.Z.; Newton, C.C.; Silverman, D.T.; Pollak, M.; Nogueira, L.M.; Weinstein, S.J.; Albanes, D.; Mannisto, S.; Jacobs, E.J. Circulating Leptin and Risk of Pancreatic Cancer: A Pooled Analysis From 3 Cohorts. Am. J. Epidemiol. 2015, 182, 187-197. [CrossRef]

92. Babic, A.; Bao, Y.; Qian, Z.R.; Yuan, C.; Giovannucci, E.L.; Aschard, H.; Kraft, P.; Amundadottir, L.T.; Stolzenberg-Solomon, R.; Morales-Oyarvide, V.; et al. Pancreatic Cancer Risk Associated with Prediagnostic Plasma Levels of Leptin and Leptin Receptor Genetic Polymorphisms. Cancer Res. 2016, 76, 7160-7167. [CrossRef]

93. Dimou, N.L.; Papadimitriou, N.; Mariosa, D.; Johansson, M.; Brennan, P.; Peters, U.; Chanock, S.J.; Purdue, M.; Bishop, D.T.; GagoDominquez, M.; et al. Circulating adipokine concentrations and risk of five obesity-related cancers: A Mendelian randomization study. Int. J. Cancer 2021, 148, 1625-1636. [CrossRef]

94. Lanza-Jacoby, S.; Yan, G.; Radice, G.; LePhong, C.; Baliff, J.; Hess, R. Calorie restriction delays the progression of lesions to pancreatic cancer in the LSL-KrasG12D.; Pdx-1/Cre mouse model of pancreatic cancer. Exp. Biol. Med. 2013, 238, 787-797. [CrossRef]

95. Eibl, G. Endocrine-exocrine signals in obesity-associated pancreatic cancer. Nat. Rev. Gastroenterol. Hepatol. 2020, 17, 455-456. [CrossRef]

96. Xu, M.; Chang, H.H.; Jung, X.; Moro, A.; Chou, C.E.N.; King, J.; Hines, O.J.; Sinnett-Smith, J.; Rozengurt, E.; Eibl, G. Deficiency in hormone-sensitive lipase accelerates the development of pancreatic cancer in conditional KrasG12D mice. BMC Cancer 2018, 18, 797. [CrossRef]

97. Xu, Y.; Tan, M.; Tian, X.; Zhang, J.; Zhang, J.; Chen, J.; Xu, W.; Sheng, H. Leptin receptor mediates the proliferation and glucose metabolism of pancreatic cancer cells via AKT pathway activation. Mol. Med. Rep. 2020, 21, 945-952. [CrossRef]

98. Fan, Y.; Gan, Y.; Shen, Y.; Cai, X.; Song, Y.; Zhao, F.; Yao, M.; Gu, J.; Tu, H. Leptin signaling enhances cell invasion and promotes the metastasis of human pancreatic cancer via increasing MMP-13 production. Oncotarget 2015, 6, 16120-16134. [CrossRef] [PubMed]

99. Mendonsa, A.M.; Chalfant, M.C.; Gorden, L.D.; VanSaun, M.N. Modulation of the leptin receptor mediates tumor growth and migration of pancreatic cancer cells. PLoS ONE 2015, 10, e0126686. [CrossRef]

100. Harbuzariu, A.; Gonzalez-Perez, R.R. Leptin-Notch axis impairs 5-fluorouracil effects on pancreatic cancer. Oncotarget 2018, 9 , 18239-18253. [CrossRef] [PubMed]

101. Candelaria, P.V.; Rampoldi, A.; Harbuzariu, A.; Gonzalez-Perez, R.R. Leptin signaling and cancer chemoresistance: Perspectives. World J. Clin. Oncol. 2017, 8, 106-119. [CrossRef] [PubMed]

102. Harbuzariu, A.; Rampoldi, A.; Daley-Brown, D.S.; Candelaria, P.; Harmon, T.L.; Lipsey, C.C.; Beech, D.J.; Quarshie, A.; Oprea Ilies, G.; Gonzalez-Perez, R.R. Leptin-Notch signaling axis is involved in pancreatic cancer progression. Oncotarget 2016, 8, 7740-7752. [CrossRef]

103. Scherer, P.E.; Williams, S.; Fogliano, M.; Baldini, G.; Lodish, H.F. A novel serum protein similar to C1q, produced exclusively in adipocytes. J. Biol. Chem. 1995, 270, 26746-26749. [CrossRef]

104. Straub, L.G.; Scherer, P.E. Metabolic Messengers: Adiponectin. Nat. Metab. 2019, 1, 334-339. [CrossRef]

105. Wang, Z.V.; Scherer, P.E. Adiponectin, the past two decades. J. Mol. Cell Biol. 2016, 8, 93-100. [CrossRef] 
106. Dalamaga, M.; Diakopoulos, K.N.; Mantzoros, C.S. The role of adiponectin in cancer: A review of current evidence. Endocr. Rev. 2012, 33, 547-594. [CrossRef] [PubMed]

107. Arita, Y.; Kihara, S.; Ouchi, N.; Takahashi, M.; Maeda, K.; Miyagawa, J.; Hotta, K.; Shimomura, I.; Nakamura, T.; Miyaoka, K.; et al. Paradoxical decrease of an adipose-specific protein, adiponectin, in obesity. Biochem. Biophys. Res. Commun. 1999, $257,79-83$. [CrossRef] [PubMed]

108. Gariballa, S.; Alkaabi, J.; Yasin, J.; Al Essa, A. Total adiponectin in overweight and obese subjects and its response to visceral fat loss. BMC Endocr. Disord. 2019, 19, 55. [CrossRef] [PubMed]

109. Stolzenberg-Solomon, R.Z.; Weinstein, S.; Pollak, M.; Tao, Y.; Taylor, P.R.; Virtamo, J.; Albanes, D. Prediagnostic adiponectin concentrations and pancreatic cancer risk in male smokers. Am. J. Epidemiol. 2008, 168, 1047-1055. [CrossRef]

110. Bao, Y.; Giovannucci, E.L.; Kraft, P.; Stampfer, M.J.; Ogino, S.; Ma, J.; Buring, J.E.; Sesso, H.D.; Lee, I.M.; Gaziano, J.M.; et al. A prospective study of plasma adiponectin and pancreatic cancer risk in five US cohorts. J. Natl. Cancer Inst. 2013, 105, 95-103. [CrossRef]

111. Grote, V.A.; Rohrmann, S.; Dossus, L.; Nieters, A.; Halkjaer, J.; Tjonneland, A.; Overvad, K.; Stegger, J.; Chabbert-Buffet, N.; Boutron-Ruault, M.C.; et al. The association of circulating adiponectin levels with pancreatic cancer risk: A study within the prospective EPIC cohort. Int. J. Cancer 2012, 130, 2428-2437. [CrossRef]

112. Nogueira, L.M.; Newton, C.C.; Pollak, M.N.; Silverman, D.T.; Albanes, D.; Mannisto, S.; Weinstein, S.J.; Jacobs, E.J.; StolzenbergSolomon, R.Z. Serum C-peptide, total and high molecular weight adiponectin, and pancreatic cancer: Do associations differ by smoking? Cancer Epidemiol. Biomark. Prev. 2017, 26, 914-922. [CrossRef]

113. Dalamaga, M.; Migdalis, I.; Fargnoli, J.L.; Papadavid, E.; Bloom, E.; Mitsiades, N.; Karmaniolas, K.; Pelecanos, N.; TseleniBalafouta, S.; Dionyssiou-Asteriou, A.; et al. Pancreatic cancer expresses adiponectin receptors and is associated with hypoleptinemia and hyperadiponectinemia: A case-control study. Cancer Causes Control 2009, 20, 625-633. [CrossRef] [PubMed]

114. Dranka-Bojarowska, D.; Lekstan, A.; Olakowski, M.; Jablonska, B.; Lewinski, A.; Musialski, P.; Sobczyk, W.; Kapalka, A.; Lampe, P. The assessment of serum concentration of adiponectin, leptin and serum carbohydrate antigen-19.9 in patients with pancreatic cancer and chronic pancreatitis. J. Physiol. Pharmacol. 2015, 66, 653-663. [PubMed]

115. Krechler, T.; Zeman, M.; Vecka, M.; Macasek, J.; Jachymova, M.; Zima, T.; Zak, A. Leptin and adiponectin in pancreatic cancer: Connection with diabetes mellitus. Neoplasma 2011, 58, 58-64. [CrossRef]

116. Messaggio, F.; Mendonsa, A.M.; Castellanos, J.; Nagathihalli, N.S.; Gorden, L.; Merchant, N.B.; VanSaun, M.N. Adiponectin receptor agonists inhibit leptin induced pSTAT3 and in vivo pancreatic tumor growth. Oncotarget 2017, 8, 85378-85391. [CrossRef]

117. Akimoto, M.; Maruyama, R.; Kawabata, Y.; Tajima, Y.; Takenaga, K. Antidiabetic adiponectin receptor agonist AdipoRon suppresses tumour growth of pancreatic cancer by inducing RIPK1/ERK-dependent necroptosis. Cell Death Dis. 2018, 9, 804. [CrossRef]

118. Jiang, J.; Fan, Y.; Zhang, W.; Shen, Y.; Liu, T.; Yao, M.; Gu, J.; Tu, H.; Gan, Y. Adiponectin Suppresses Human Pancreatic Cancer Growth through Attenuating the beta-Catenin Signaling Pathway. Int. J. Biol. Sci. 2019, 15, 253-264. [CrossRef] [PubMed]

119. Kato, M.; Watabe, K.; Tsujii, M.; Funahashi, T.; Shimomura, I.; Takehara, T. Adiponectin inhibits murine pancreatic cancer growth Dig. Dis. Sci. 2014, 59, 1192-1196. [CrossRef]

120. Takenaga, K.; Akimoto, M.; Koshikawa, N.; Nagase, H. Obesity reduces the anticancer effect of AdipoRon against orthotopic pancreatic cancer in diet-induced obese mice. Sci. Rep. 2021, 11, 2923. [CrossRef]

121. Flower, D.R. The lipocalin protein family: Structure and function. Biochem. J. 1996, 318 Pt 1, 1-14. [CrossRef]

122. Moschen, A.R.; Adolph, T.E.; Gerner, R.R.; Wieser, V.; Tilg, H. Lipocalin-2: A Master Mediator of Intestinal and Metabolic Inflammation. Trends Endocrinol. Metab. 2017, 28, 388-397. [CrossRef] [PubMed]

123. Xiao, X.; Yeoh, B.S.; Vijay-Kumar, M. Lipocalin 2: An Emerging Player in Iron Homeostasis and Inflammation. Annu. Rev. Nutr. 2017, 37, 103-130. [CrossRef] [PubMed]

124. Zhang, Y.; Foncea, R.; Deis, J.A.; Guo, H.; Bernlohr, D.A.; Chen, X. Lipocalin 2 expression and secretion is highly regulated by metabolic stress, cytokines, and nutrients in adipocytes. PLoS ONE 2014, 9, e96997. [CrossRef] [PubMed]

125. Yan, Q.W.; Yang, Q.; Mody, N.; Graham, T.E.; Hsu, C.H.; Xu, Z.; Houstis, N.E.; Kahn, B.B.; Rosen, E.D. The adipokine lipocalin 2 is regulated by obesity and promotes insulin resistance. Diabetes 2007, 56, 2533-2540. [CrossRef] [PubMed]

126. Wang, Y.; Lam, K.S.; Kraegen, E.W.; Sweeney, G.; Zhang, J.; Tso, A.W.; Chow, W.S.; Wat, N.M.; Xu, J.Y.; Hoo, R.L.; et al. Lipocalin2 is an inflammatory marker closely associated with obesity, insulin resistance, and hyperglycemia in humans. Clin. Chem. 2007, 53, 34-41. [CrossRef]

127. Gumpper, K.; Dangel, A.W.; Pita-Grisanti, V.; Krishna, S.G.; Lara, L.F.; Mace, T.; Papachristou, G.I.; Conwell, D.L.; Hart, P.A.; Cruz-Monserrate, Z. Lipocalin-2 expression and function in pancreatic diseases. Pancreatology 2020, 20, 419-424. [CrossRef] [PubMed]

128. Olson, B.; Zhu, X.; Norgard, M.A.; Levasseur, P.R.; Butler, J.T.; Buenafe, A.; Burfeind, K.G.; Michaelis, K.A.; Pelz, K.R.; Mendez, H.; et al. Lipocalin 2 mediates appetite suppression during pancreatic cancer cachexia. Nat. Commun. 2021, 12, 2057. [CrossRef]

129. Moniaux, N.; Chakraborty, S.; Yalniz, M.; Gonzalez, J.; Shostrom, V.K.; Standop, J.; Lele, S.M.; Ouellette, M.; Pour, P.M.; Sasson, A.R.; et al. Early diagnosis of pancreatic cancer: Neutrophil gelatinase-associated lipocalin as a marker of pancreatic intraepithelial neoplasia. Br. J. Cancer 2008, 98, 1540-1547. [CrossRef]

130. Kaur, S.; Chakraborty, S.; Baine, M.J.; Mallya, K.; Smith, L.M.; Sasson, A.; Brand, R.; Guha, S.; Jain, M.; Wittel, U.; et al. Potentials of plasma NGAL and MIC-1 as biomarker(s) in the diagnosis of lethal pancreatic cancer. PLoS ONE 2013, 8, e55171. [CrossRef] 
131. Kaur, S.; Sharma, N.; Krishn, S.R.; Lakshmanan, I.; Rachagani, S.; Baine, M.J.; Smith, L.M.; Lele, S.M.; Sasson, A.R.; Guha, S.; et al. MUC4-mediated regulation of acute phase protein lipocalin 2 through HER2/AKT/NF-kappaB signaling in pancreatic cancer. Clin. Cancer Res. 2014, 20, 688-700. [CrossRef]

132. Tong, Z.; Kunnumakkara, A.B.; Wang, H.; Matsuo, Y.; Diagaradjane, P.; Harikumar, K.B.; Ramachandran, V.; Sung, B.; Chakraborty, A.; Bresalier, R.S.; et al. Neutrophil gelatinase-associated lipocalin: A novel suppressor of invasion and angiogenesis in pancreatic cancer. Cancer Res. 2008, 68, 6100-6108. [CrossRef]

133. Xu, B.; Jin, D.Y.; Lou, W.H.; Wang, D.S. Lipocalin-2 is associated with a good prognosis and reversing epithelial-to-mesenchymal transition in pancreatic cancer. World J. Surg. 2013, 37, 1892-1900. [CrossRef]

134. Leung, L.; Radulovich, N.; Zhu, C.Q.; Organ, S.; Bandarchi, B.; Pintilie, M.; To, C.; Panchal, D.; Tsao, M.S. Lipocalin2 promotes invasion, tumorigenicity and gemcitabine resistance in pancreatic ductal adenocarcinoma. PLoS ONE 2012, 7, e46677. [CrossRef]

135. Gomez-Chou, S.B.; Swidnicka-Siergiejko, A.K.; Badi, N.; Chavez-Tomar, M.; Lesinski, G.B.; Bekaii-Saab, T.; Farren, M.R.; Mace, T.A.; Schmidt, C.; Liu, Y.; et al. Lipocalin-2 Promotes Pancreatic Ductal Adenocarcinoma by Regulating Inflammation in the Tumor Microenvironment. Cancer Res. 2017, 77, 2647-2660. [CrossRef]

136. Nishimura, T.; Nakatake, Y.; Konishi, M.; Itoh, N. Identification of a novel FGF, FGF-21, preferentially expressed in the liver. Biochim. Biophys. Acta 2000, 1492, 203-206. [CrossRef]

137. Kharitonenkov, A.; Shiyanova, T.L.; Koester, A.; Ford, A.M.; Micanovic, R.; Galbreath, E.J.; Sandusky, G.E.; Hammond, L.J.; Moyers, J.S.; Owens, R.A.; et al. FGF-21 as a novel metabolic regulator. J. Clin. Investig. 2005, 115, 1627-1635. [CrossRef] [PubMed]

138. Han, M.S.; Perry, R.J.; Camporez, J.P.; Scherer, P.E.; Shulman, G.I.; Gao, G.; Davis, R.J. A feed-forward regulatory loop in adipose tissue promotes signaling by the hepatokine FGF21. Genes Dev. 2021, 35, 133-146. [CrossRef] [PubMed]

139. Foltz, I.N.; Hu, S.; King, C.; Wu, X.; Yang, C.; Wang, W.; Weiszmann, J.; Stevens, J.; Chen, J.S.; Nuanmanee, N.; et al. Treating diabetes and obesity with an FGF21-mimetic antibody activating the betaKlotho/FGFR1c receptor complex. Sci. Transl. Med. 2012, 4, 162ra153. [CrossRef] [PubMed]

140. Gaich, G.; Chien, J.Y.; Fu, H.; Glass, L.C.; Deeg, M.A.; Holland, W.L.; Kharitonenkov, A.; Bumol, T.; Schilske, H.K.; Moller, D.E. The effects of LY2405319, an FGF21 analog, in obese human subjects with type 2 diabetes. Cell Metab. 2013, 18, 333-340. [CrossRef]

141. Talukdar, S.; Zhou, Y.; Li, D.; Rossulek, M.; Dong, J.; Somayaji, V.; Weng, Y.; Clark, R.; Lanba, A.; Owen, B.M.; et al. A Long-Acting FGF21 Molecule, PF-05231023, Decreases Body Weight and Improves Lipid Profile in Non-human Primates and Type 2 Diabetic Subjects. Cell Metab. 2016, 23, 427-440. [CrossRef]

142. Wu, A.L.; Kolumam, G.; Stawicki, S.; Chen, Y.; Li, J.; Zavala-Solorio, J.; Phamluong, K.; Feng, B.; Li, L.; Marsters, S.; et al. Amelioration of type 2 diabetes by antibody-mediated activation of fibroblast growth factor receptor 1. Sci. Transl. Med. 2011, 3, 113ra126. [CrossRef]

143. Flippo, K.H.; Potthoff, M.J. Metabolic Messengers: FGF21. Nat. Metab. 2021, 3, 309-317. [CrossRef]

144. BonDurant, L.D.; Potthoff, M.J. Fibroblast Growth Factor 21: A Versatile Regulator of Metabolic Homeostasis. Annu. Rev. Nutr. 2018, 38, 173-196. [CrossRef]

145. Coskun, T.; Bina, H.A.; Schneider, M.A.; Dunbar, J.D.; Hu, C.C.; Chen, Y.; Moller, D.E.; Kharitonenkov, A. Fibroblast growth factor 21 corrects obesity in mice. Endocrinology 2008, 149, 6018-6027. [CrossRef]

146. Xu, J.; Lloyd, D.J.; Hale, C.; Stanislaus, S.; Chen, M.; Sivits, G.; Vonderfecht, S.; Hecht, R.; Li, Y.S.; Lindberg, R.A.; et al. Fibroblast growth factor 21 reverses hepatic steatosis, increases energy expenditure, and improves insulin sensitivity in diet-induced obese mice. Diabetes 2009, 58, 250-259. [CrossRef]

147. Luo, Y.; Yang, Y.; Liu, M.; Wang, D.; Wang, F.; Bi, Y.; Ji, J.; Li, S.; Liu, Y.; Chen, R.; et al. Oncogenic KRAS Reduces Expression of FGF21 in Acinar Cells to Promote Pancreatic Tumorigenesis in Mice on a High-Fat Diet. Gastroenterology 2019, 157, 1413-1428.e11. [CrossRef]

148. Lu, W.; Li, X.; Luo, Y. FGF21 in obesity and cancer: New insights. Cancer Lett. 2021, 499, 5-13. [CrossRef]

149. Luo, Y.; Li, X.; Ma, J.; Abbruzzese, J.L.; Lu, W. Pancreatic Tumorigenesis: Oncogenic KRAS and the Vulnerability of the Pancreas to Obesity. Cancers 2021, 13, 778. [CrossRef] [PubMed]

150. Hernandez, G.; Luo, T.; Javed, T.A.; Wen, L.; Kalwat, M.A.; Vale, K.; Ammouri, F.; Husain, S.Z.; Kliewer, S.A.; Mangelsdorf, D.J. Pancreatitis is an FGF21-deficient state that is corrected by replacement therapy. Sci. Transl. Med. 2020, 12, eaay5186. [CrossRef] [PubMed]

151. Koutaki, D.; Michos, A.; Bacopoulou, F.; Charmandari, E. The Emerging Role of Sfrp5 and Wnt5a in the Pathogenesis of Obesity: Implications for a Healthy Diet and Lifestyle. Nutrients 2021, 13, 2459. [CrossRef] [PubMed]

152. Ouchi, N.; Higuchi, A.; Ohashi, K.; Oshima, Y.; Gokce, N.; Shibata, R.; Akasaki, Y.; Shimono, A.; Walsh, K. Sfrp5 is an antiinflammatory adipokine that modulates metabolic dysfunction in obesity. Science 2010, 329, 454-457. [CrossRef]

153. Catalan, V.; Gomez-Ambrosi, J.; Rodriguez, A.; Perez-Hernandez, A.I.; Gurbindo, J.; Ramirez, B.; Mendez-Gimenez, L.; Rotellar, F.; Valenti, V.; Moncada, R.; et al. Activation of noncanonical Wnt signaling through WNT5A in visceral adipose tissue of obese subjects is related to inflammation. J. Clin. Endocrinol. Metab. 2014, 99, E1407-E1417. [CrossRef] [PubMed]

154. Zuriaga, M.A.; Fuster, J.J.; Farb, M.G.; MacLauchlan, S.; Breton-Romero, R.; Karki, S.; Hess, D.T.; Apovian, C.M.; Hamburg, N.M.; Gokce, N.; et al. Activation of non-canonical WNT signaling in human visceral adipose tissue contributes to local and systemic inflammation. Sci. Rep. 2017, 7, 17326. [CrossRef] [PubMed]

155. Bo, H.; Zhang, S.; Gao, L.; Chen, Y.; Zhang, J.; Chang, X.; Zhu, M. Upregulation of Wnt5a promotes epithelial-to-mesenchymal transition and metastasis of pancreatic cancer cells. BMC Cancer 2013, 13, 496. [CrossRef] [PubMed] 
156. Zoico, E.; Darra, E.; Rizzatti, V.; Budui, S.; Franceschetti, G.; Mazzali, G.; Rossi, A.P.; Fantin, F.; Menegazzi, M.; Cinti, S.; et al. Adipocytes WNT5a mediated dedifferentiation: A possible target in pancreatic cancer microenvironment. Oncotarget 2016, 7, 20223-20235. [CrossRef] [PubMed]

157. Tu, B.; Yao, J.; Ferri-Borgogno, S.; Zhao, J.; Chen, S.; Wang, Q.; Yan, L.; Zhou, X.; Zhu, C.; Bang, S.; et al. YAP1 oncogene is a context-specific driver for pancreatic ductal adenocarcinoma. JCI Insight 2019, 4, e130811. [CrossRef] [PubMed]

158. Schaefer, J.H. The normal weight of the pancreas in the adult human being: A biometric study. Anat. Rec. 1926, 32, 119-132. [CrossRef]

159. Smits, M.M.; van Geenen, E.J. The clinical significance of pancreatic steatosis. Nat. Rev. Gastroenterol. Hepatol. 2011, 8, 169-177. [CrossRef] [PubMed]

160. Singh, R.G.; Yoon, H.D.; Wu, L.M.; Lu, J.; Plank, L.D.; Petrov, M.S. Ectopic fat accumulation in the pancreas and its clinical relevance: A systematic review, meta-analysis, and meta-regression. Metabolism 2017, 69, 1-13. [CrossRef]

161. Singh, R.G.; Yoon, H.D.; Poppitt, S.D.; Plank, L.D.; Petrov, M.S. Ectopic fat accumulation in the pancreas and its biomarkers: A systematic review and meta-analysis. Diabetes Metab. Res. Rev. 2017, 33, e2918. [CrossRef]

162. Sreedhar, U.L.; DeSouza, S.V.; Park, B.; Petrov, M.S. A Systematic Review of Intra-pancreatic Fat Deposition and Pancreatic Carcinogenesis. J. Gastrointest. Surg. 2020, 24, 2560-2569. [CrossRef]

163. Olsen, T.S. Lipomatosis of the pancreas in autopsy material and its relation to age and overweight. Acta Pathol. Microbiol. Scand. A 1978, 86, 367-373. [CrossRef] [PubMed]

164. Schmitz-Moormann, P.; Pittner, P.M.; Heinze, W. Lipomatosis of the pancreas. A morphometrical investigation. Pathol. Res. Pract. 1981, 173, 45-53. [CrossRef]

165. Takahashi, M.; Hori, M.; Ishigamori, R.; Mutoh, M.; Imai, T.; Nakagama, H. Fatty pancreas: A possible risk factor for pancreatic cancer in animals and humans. Cancer Sci. 2018, 109, 3013-3023. [CrossRef] [PubMed]

166. Lee, Y.; Hirose, H.; Ohneda, M.; Johnson, J.H.; McGarry, J.D.; Unger, R.H. Beta-cell lipotoxicity in the pathogenesis of non-insulindependent diabetes mellitus of obese rats: Impairment in adipocyte-beta-cell relationships. Proc. Natl. Acad. Sci. USA 1994, 91, 10878-10882. [CrossRef] [PubMed]

167. Taylor, R. Pathogenesis of type 2 diabetes: Tracing the reverse route from cure to cause. Diabetologia 2008, 51, 1781-1789. [CrossRef]

168. Yan, M.X.; Li, Y.Q.; Meng, M.; Ren, H.B.; Kou, Y. Long-term high-fat diet induces pancreatic injuries via pancreatic microcirculatory disturbances and oxidative stress in rats with hyperlipidemia. Biochem. Biophys. Res. Commun. 2006, 347, 192-199. [CrossRef]

169. Pinnick, K.E.; Collins, S.C.; Londos, C.; Gauguier, D.; Clark, A.; Fielding, B.A. Pancreatic ectopic fat is characterized by adipocyte infiltration and altered lipid composition. Obesity 2008, 16, 522-530. [CrossRef] [PubMed]

170. Seeberger, K.L.; Dufour, J.M.; Shapiro, A.M.; Lakey, J.R.; Rajotte, R.V.; Korbutt, G.S. Expansion of mesenchymal stem cells from human pancreatic ductal epithelium. Lab. Investig. 2006, 86, 141-153. [CrossRef]

171. Zhang, Y.; Daquinag, A.; Traktuev, D.O.; Amaya-Manzanares, F.; Simmons, P.J.; March, K.L.; Pasqualini, R.; Arap, W.; Kolonin, M.G. White adipose tissue cells are recruited by experimental tumors and promote cancer progression in mouse models. Cancer Res. 2009, 69, 5259-5266. [CrossRef]

172. Zhang, Y.; Daquinag, A.C.; Amaya-Manzanares, F.; Sirin, O.; Tseng, C.; Kolonin, M.G. Stromal progenitor cells from endogenous adipose tissue contribute to pericytes and adipocytes that populate the tumor microenvironment. Cancer Res. 2012, 72, 5198-5208. [CrossRef]

173. Gupta, O.T.; Gupta, R.K. Visceral Adipose Tissue Mesothelial Cells: Living on the Edge or Just Taking Up Space? Trends Endocrinol. Metab. 2015, 26, 515-523. [CrossRef]

174. Abe, T.; Ohuchida, K.; Koikawa, K.; Endo, S.; Okumura, T.; Sada, M.; Horioka, K.; Zheng, B.; Moriyama, T.; Nakata, K.; et al. Cancer-associated peritoneal mesothelial cells lead the formation of pancreatic cancer peritoneal dissemination. Int. J. Oncol. 2017, 50, 457-467. [CrossRef]

175. Chau, Y.Y.; Bandiera, R.; Serrels, A.; Martinez-Estrada, O.M.; Qing, W.; Lee, M.; Slight, J.; Thornburn, A.; Berry, R.; McHaffie, S.; et al. Visceral and subcutaneous fat have different origins and evidence supports a mesothelial source. Nat. Cell Biol. 2014, 16, 367-375. [CrossRef] [PubMed]

176. Ariza, L.; Rojas, A.; Munoz-Chapuli, R.; Carmona, R. The Wilms' tumor suppressor gene regulates pancreas homeostasis and repair. PLoS Genet. 2019, 15, e1007971. [CrossRef] [PubMed]

177. Westcott, G.P.; Emont, M.P.; Li, J.; Jacobs, C.; Tsai, L.; Rosen, E.D. Mesothelial cells are not a source of adipocytes in mice. Cell Rep. 2021, 36, 109388. [CrossRef] [PubMed]

178. Bonal, C.; Thorel, F.; Ait-Lounis, A.; Reith, W.; Trumpp, A.; Herrera, P.L. Pancreatic inactivation of c-Myc decreases acinar mass and transdifferentiates acinar cells into adipocytes in mice. Gastroenterology 2009, 136, 309-319.e9. [CrossRef]

179. Zha, M.; Xu, W.; Jones, P.M.; Sun, Z. Isolation and characterization of human islet stellate cells. Exp. Cell Res. 2016, 341, 61-66. [CrossRef]

180. Lengyel, E.; Makowski, L.; DiGiovanni, J.; Kolonin, M.G. Cancer as a Matter of Fat: The Crosstalk between Adipose Tissue and Tumors. Trends Cancer 2018, 4, 374-384. [CrossRef]

181. Wolpin, B.M.; Bao, Y.; Qian, Z.R.; Wu, C.; Kraft, P.; Ogino, S.; Stampfer, M.J.; Sato, K.; Ma, J.; Buring, J.E.; et al. Hyperglycemia, insulin resistance, impaired pancreatic beta-cell function, and risk of pancreatic cancer. J. Natl. Cancer Inst. 2013, 105, 1027-1035. [CrossRef] 
182. Andersen, D.K.; Korc, M.; Petersen, G.M.; Eibl, G.; Li, D.; Rickels, M.R.; Chari, S.T.; Abbruzzese, J.L. Diabetes, Pancreatogenic Diabetes, and Pancreatic Cancer. Diabetes 2017, 66, 1103-1110. [CrossRef]

183. Hao, F.; Xu, Q.; Zhao, Y.; Stevens, J.V.; Young, S.H.; Sinnett-Smith, J.; Rozengurt, E. Insulin Receptor and GPCR Crosstalk Stimulates YAP via PI3K and PKD in Pancreatic Cancer Cells. Mol. Cancer Res. 2017, 15, 929-941. [CrossRef]

184. Kisfalvi, K.; Eibl, G.; Sinnett-Smith, J.; Rozengurt, E. Metformin disrupts crosstalk between G protein-coupled receptor and insulin receptor signaling systems and inhibits pancreatic cancer growth. Cancer Res. 2009, 69, 6539-6545. [CrossRef]

185. Rozengurt, E.; Sinnett-Smith, J.; Kisfalvi, K. Crosstalk between insulin/insulin-like growth factor-1 receptors and G proteincoupled receptor signaling systems: A novel target for the antidiabetic drug metformin in pancreatic cancer. Clin. Cancer Res. 2010, 16, 2505-2511. [CrossRef]

186. Rozengurt, E. Mechanistic target of rapamycin (mTOR): A point of convergence in the action of insulin/IGF-1 and G proteincoupled receptor agonists in pancreatic cancer cells. Front. Physiol. 2014, 5, 357. [CrossRef]

187. Young, S.H.; Rozengurt, E. Crosstalk between insulin receptor and G protein-coupled receptor signaling systems leads to Ca(2)+ oscillations in pancreatic cancer PANC-1 cells. Biochem. Biophys. Res. Commun. 2010, 401, 154-158. [CrossRef]

188. Kisfalvi, K.; Rey, O.; Young, S.H.; Sinnett-Smith, J.; Rozengurt, E. Insulin potentiates $\mathrm{Ca}^{2+}$ signaling and phosphatidylinositol 4,5bisphosphate hydrolysis induced by Gq protein-coupled receptor agonists through an mTOR-dependent pathway. Endocrinology 2007, 148, 3246-3257. [CrossRef]

189. Ming, M.; Sinnett-Smith, J.; Wang, J.; Soares, H.P.; Young, S.H.; Eibl, G.; Rozengurt, E. Dose-Dependent AMPK-Dependent and Independent Mechanisms of Berberine and Metformin Inhibition of mTORC1, ERK, DNA Synthesis and Proliferation in Pancreatic Cancer Cells. PLoS ONE 2014, 9, e114573. [CrossRef] [PubMed]

190. Eibl, G.; Rozengurt, E. KRAS, YAP, and obesity in pancreatic cancer: A signaling network with multiple loops. Semin. Cancer Biol. 2019, 54, 50-62. [CrossRef] [PubMed]

191. Greten, F.R. YAP1 takes over when oncogenic K-Ras slumbers. Cell 2014, 158, 11-12. [CrossRef] [PubMed]

192. Gruber, R.; Panayiotou, R.; Nye, E.; Spencer-Dene, B.; Stamp, G.; Behrens, A. YAP1 and TAZ Control Pancreatic Cancer Initiation in Mice by Direct Up-regulation of JAK-STAT3 Signaling. Gastroenterology 2016, 151, 526-539. [CrossRef] [PubMed]

193. Kapoor, A.; Yao, W.; Ying, H.; Hua, S.; Liewen, A.; Wang, Q.; Zhong, Y.; Wu, C.J.; Sadanandam, A.; Hu, B.; et al. Yap1 activation enables bypass of oncogenic Kras addiction in pancreatic cancer. Cell 2014, 158, 185-197. [CrossRef]

194. Morvaridi, S.; Dhall, D.; Greene, M.I.; Pandol, S.J.; Wang, Q. Role of YAP and TAZ in pancreatic ductal adenocarcinoma and in stellate cells associated with cancer and chronic pancreatitis. Sci. Rep. 2015, 5, 16759. [CrossRef]

195. Rozengurt, E.; Sinnett-Smith, J.; Eibl, G. Yes-associated protein (YAP) in pancreatic cancer: At the epicenter of a targetable signaling network associated with patient survival. Signal Transduct. Target. Ther. 2018, 3, 11. [CrossRef]

196. Zhang, W.; Nandakumar, N.; Shi, Y.; Manzano, M.; Smith, A.; Graham, G.; Gupta, S.; Vietsch, E.E.; Laughlin, S.Z.; Wadhwa, M.; et al. Downstream of mutant KRAS, the transcription regulator YAP is essential for neoplastic progression to pancreatic ductal adenocarcinoma. Sci. Signal. 2014, 7, ra42. [CrossRef]

197. Rozengurt, E.; Eibl, G. Central role of Yes-associated protein and WW-domain-containing transcriptional co-activator with PDZ-binding motif in pancreatic cancer development. World J. Gastroenterol. 2019, 25, 1797-1816. [CrossRef]

198. Li, J.; Song, J.; Zaytseva, Y.Y.; Liu, Y.; Rychahou, P.; Jiang, K.; Starr, M.E.; Kim, J.T.; Harris, J.W.; Yiannikouris, F.B.; et al. An obligatory role for neurotensin in high-fat-diet-induced obesity. Nature 2016, 533, 411-415. [CrossRef]

199. Eibl, G.; Rozengurt, E. Metformin: Review of epidemiology and mechanisms of action in pancreatic cancer. Cancer Metastasis Rev. 2021. [CrossRef]

200. Menini, S.; Iacobini, C.; de Latouliere, L.; Manni, I.; Ionta, V.; Blasetti Fantauzzi, C.; Pesce, C.; Cappello, P.; Novelli, F.; Piaggio, G.; et al. The advanced glycation end-product $\mathrm{N}^{\epsilon}$-carboxymethyllysine promotes progression of pancreatic cancer: Implications for diabetes-associated risk and its prevention. J. Pathol. 2018, 245, 197-208. [CrossRef]

201. Azizan, N.; Suter, M.A.; Liu, Y.; Logsdon, C.D. RAGE maintains high levels of NFkappaB and oncogenic Kras activity in pancreatic cancer. Biochem. Biophys. Res. Commun. 2017, 493, 592-597. [CrossRef]

202. Garay-Sevilla, M.E.; Gomez-Ojeda, A.; Gonzalez, I.; Luevano-Contreras, C.; Rojas, A. Contribution of RAGE axis activation to the association between metabolic syndrome and cancer. Mol. Cell Biochem. 2021, 476, 1555-1573. [CrossRef]

203. Boulange, C.L.; Neves, A.L.; Chilloux, J.; Nicholson, J.K.; Dumas, M.E. Impact of the gut microbiota on inflammation, obesity, and metabolic disease. Genome Med. 2016, 8, 42. [CrossRef]

204. Maruvada, P.; Leone, V.; Kaplan, L.M.; Chang, E.B. The Human Microbiome and Obesity: Moving beyond Associations. Cell Host Microbe 2017, 22, 589-599. [CrossRef]

205. Bouter, K.E.; van Raalte, D.H.; Groen, A.K.; Nieuwdorp, M. Role of the Gut Microbiome in the Pathogenesis of Obesity and Obesity-Related Metabolic Dysfunction. Gastroenterology 2017, 152, 1671-1678. [CrossRef] [PubMed]

206. Turnbaugh, P.J.; Ley, R.E.; Mahowald, M.A.; Magrini, V.; Mardis, E.R.; Gordon, J.I. An obesity-associated gut microbiome with increased capacity for energy harvest. Nature 2006, 444, 1027-1031. [CrossRef] [PubMed]

207. Cani, P.D.; Bibiloni, R.; Knauf, C.; Waget, A.; Neyrinck, A.M.; Delzenne, N.M.; Burcelin, R. Changes in gut microbiota control metabolic endotoxemia-induced inflammation in high-fat diet-induced obesity and diabetes in mice. Diabetes 2008, 57, 1470-1481. [CrossRef] [PubMed]

208. Ley, R.E.; Backhed, F.; Turnbaugh, P.; Lozupone, C.A.; Knight, R.D.; Gordon, J.I. Obesity alters gut microbial ecology. Proc. Natl. Acad. Sci. USA 2005, 102, 11070-11075. [CrossRef] 
209. Ussar, S.; Griffin, N.W.; Bezy, O.; Fujisaka, S.; Vienberg, S.; Softic, S.; Deng, L.; Bry, L.; Gordon, J.I.; Kahn, C.R. Interactions between Gut Microbiota, Host Genetics and Diet Modulate the Predisposition to Obesity and Metabolic Syndrome. Cell Metab. 2015, 22, 516-530. [CrossRef]

210. Ridaura, V.K.; Faith, J.J.; Rey, F.E.; Cheng, J.; Duncan, A.E.; Kau, A.L.; Griffin, N.W.; Lombard, V.; Henrissat, B.; Bain, J.R.; et al. Gut microbiota from twins discordant for obesity modulate metabolism in mice. Science 2013, 341, 1241214. [CrossRef]

211. Chen, J.; Pitmon, E.; Wang, K. Microbiome, inflammation and colorectal cancer. Semin. Immunol. 2017, 32, 43-53. [CrossRef]

212. Yoshimoto, S.; Loo, T.M.; Atarashi, K.; Kanda, H.; Sato, S.; Oyadomari, S.; Iwakura, Y.; Oshima, K.; Morita, H.; Hattori, M.; et al. Obesity-induced gut microbial metabolite promotes liver cancer through senescence secretome. Nature 2013, 499, 97-101. [CrossRef]

213. Thomas, R.M.; Gharaibeh, R.Z.; Gauthier, J.; Beveridge, M.; Pope, J.L.; Guijarro, M.V.; Yu, Q.; He, Z.; Ohland, C.; Newsome, R.; et al. Intestinal microbiota enhances pancreatic carcinogenesis in preclinical models. Carcinogenesis 2018, 39, 1068-1078. [CrossRef]

214. Cani, P.D.; Jordan, B.F. Gut microbiota-mediated inflammation in obesity: A link with gastrointestinal cancer. Nat. Rev. Gastroenterol. Hepatol. 2018, 15, 671-682. [CrossRef]

215. Sethi, V.; Kurtom, S.; Tarique, M.; Lavania, S.; Malchiodi, Z.; Hellmund, L.; Zhang, L.; Sharma, U.; Giri, B.; Garg, B.; et al. Gut Microbiota Promotes Tumor Growth in Mice by Modulating Immune Response. Gastroenterology 2018, 155, 33-37.e6. [CrossRef]

216. McAllister, F.; Khan, M.A.W.; Helmink, B.; Wargo, J.A. The Tumor Microbiome in Pancreatic Cancer: Bacteria and Beyond. Cancer Cell 2019, 36, 577-579. [CrossRef] [PubMed]

217. Riquelme, E.; Zhang, Y.; Zhang, L.; Montiel, M.; Zoltan, M.; Dong, W.; Quesada, P.; Sahin, I.; Chandra, V.; San Lucas, A.; et al. Tumor Microbiome Diversity and Composition Influence Pancreatic Cancer Outcomes. Cell 2019, 178, 795-806.e12. [CrossRef] [PubMed]

218. Pushalkar, S.; Hundeyin, M.; Daley, D.; Zambirinis, C.P.; Kurz, E.; Mishra, A.; Mohan, N.; Aykut, B.; Usyk, M.; Torres, L.E.; et al. The Pancreatic Cancer Microbiome Promotes Oncogenesis by Induction of Innate and Adaptive Immune Suppression. Cancer Discov. 2018, 8, 403-416. [CrossRef] [PubMed]

219. Aykut, B.; Pushalkar, S.; Chen, R.; Li, Q.; Abengozar, R.; Kim, J.I.; Shadaloey, S.A.; Wu, D.; Preiss, P.; Verma, N.; et al. The fungal mycobiome promotes pancreatic oncogenesis via activation of MBL. Nature 2019, 574, 264-267. [CrossRef]

220. Dong, T.S.; Chang, H.H.; Hauer, M.; Lagishetty, V.; Katzka, W.; Rozengurt, E.; Jacobs, J.P.; Eibl, G. Metformin alters the duodenal microbiome and decreases the incidence of pancreatic ductal adenocarcinoma promoted by diet-induced obesity. Am. J. Physiol. Gastrointest. Liver Physiol. 2019, 317, G763-G772. [CrossRef]

221. Ouyang, J.; Lin, J.; Isnard, S.; Fombuena, B.; Peng, X.; Marette, A.; Routy, B.; Messaoudene, M.; Chen, Y.; Routy, J.P. The Bacterium Akkermansia muciniphila: A Sentinel for Gut Permeability and Its Relevance to HIV-Related Inflammation. Front. Immunol. 2020, 11, 645. [CrossRef]

222. Fujisaka, S.; Usui, I.; Nawaz, A.; Igarashi, Y.; Okabe, K.; Furusawa, Y.; Watanabe, S.; Yamamoto, S.; Sasahara, M.; Watanabe, Y.; et al. Bofutsushosan improves gut barrier function with a bloom of Akkermansia muciniphila and improves glucose metabolism in mice with diet-induced obesity. Sci. Rep. 2020, 10, 5544. [CrossRef]

223. Chelakkot, C.; Choi, Y.; Kim, D.K.; Park, H.T.; Ghim, J.; Kwon, Y.; Jeon, J.; Kim, M.S.; Jee, Y.K.; Gho, Y.S.; et al. Akkermansia muciniphila-derived extracellular vesicles influence gut permeability through the regulation of tight junctions. Exp. Mol. Med. 2018, 50, e450. [CrossRef]

224. Dao, M.C.; Everard, A.; Aron-Wisnewsky, J.; Sokolovska, N.; Prifti, E.; Verger, E.O.; Kayser, B.D.; Levenez, F.; Chilloux, J.; Hoyles, L.; et al. Akkermansia muciniphila and improved metabolic health during a dietary intervention in obesity: Relationship with gut microbiome richness and ecology. Gut 2016, 65, 426-436. [CrossRef]

225. Yassour, M.; Lim, M.Y.; Yun, H.S.; Tickle, T.L.; Sung, J.; Song, Y.M.; Lee, K.; Franzosa, E.A.; Morgan, X.C.; Gevers, D.; et al Sub-clinical detection of gut microbial biomarkers of obesity and type 2 diabetes. Genome Med. 2016, 8, 17. [CrossRef] [PubMed]

226. Boutagy, N.E.; McMillan, R.P.; Frisard, M.I.; Hulver, M.W. Metabolic endotoxemia with obesity: Is it real and is it relevant? Biochimie 2016, 124, 11-20. [CrossRef] [PubMed]

227. Neves, A.L.; Coelho, J.; Couto, L.; Leite-Moreira, A.; Roncon-Albuquerque, R., Jr. Metabolic endotoxemia: A molecular link between obesity and cardiovascular risk. J. Mol. Endocrinol. 2013, 51, R51-64. [CrossRef] [PubMed]

228. Cani, P.D.; Amar, J.; Iglesias, M.A.; Poggi, M.; Knauf, C.; Bastelica, D.; Neyrinck, A.M.; Fava, F.; Tuohy, K.M.; Chabo, C.; et al. Metabolic endotoxemia initiates obesity and insulin resistance. Diabetes 2007, 56, 1761-1772. [CrossRef] [PubMed]

229. Osto, M.; Zini, E.; Franchini, M.; Wolfrum, C.; Guscetti, F.; Hafner, M.; Ackermann, M.; Reusch, C.E.; Lutz, T.A. Subacute endotoxemia induces adipose inflammation and changes in lipid and lipoprotein metabolism in cats. Endocrinology 2011, 152, 804-815. [CrossRef] [PubMed]

230. Ren, Z.; Jiang, J.; Xie, H.; Li, A.; Lu, H.; Xu, S.; Zhou, L.; Zhang, H.; Cui, G.; Chen, X.; et al. Gut microbial profile analysis by MiSeq sequencing of pancreatic carcinoma patients in China. Oncotarget 2017, 8, 95176-95191. [CrossRef] [PubMed]

231. Yan, S.; Jiang, Z.; Cheng, L.; Lin, Y.; Fan, B.; Luo, L.; Yan, Y.; Yang, L.; Shen, X. TLR4 knockout can improve dysfunction of beta-cell by rebalancing proteomics disorders in pancreas of obese rats. Endocrine 2020, 67, 67-79. [CrossRef] [PubMed]

232. Massoumi, R.L.; Teper, Y.; Ako, S.; Ye, L.; Wang, E.; Hines, O.J.; Eibl, G. Direct Effects of Lipopolysaccharide on Human Pancreatic Cancer Cells. Pancreas 2021, 50, 524-528. [CrossRef] [PubMed] 